Nevşehir Bilim ve Teknoloji Dergisi Cilt 6(2) 661-680 2017

DOI: 10.17100/nevbiltek.344344

URL: http://dx.doi.org/10.17100/nevbiltek.344344

\title{
Kapadokya Bölgesi İl Merkezlerinde Yaşayanların İlaç Kullanım Alışkanlıklarının Belirlenmesi
}

\author{
Soner METE*, Zeynep ÜNAL \\ Nevşehir Hacı Bektaş Veli Üniversitesi, Sağlık Hizmetleri Meslek Yüksekokulu, Nevşehir \\ $\ddot{\mathbf{O z}}$
}

Bu çalışma, Kapadokya Bölgesinde yer alan Nevşehir, Kayseri, Niğde, Aksaray ve Kırşehir il merkezlerindeki 18 yaş ve üzeri kişilerin, ilaç kullanım alışkanlıklarını ve etkileyen faktörlerin belirlenmesini amaçlamaktadır. Kapadokya bölgesi illerinin sadece il merkezlerinde yaşayan ve 18 yaş üzeri 686 kişiye yüz yüze anket yöntemi uygulanmıştır. Sonuçlar yüzde (\%) cevap olarak değerlendirilmiştir. Katılımcıların \% 77,1'i şikayetleri azaldığında ilaç kullanmayı bıraktıklarını, \% 65,3'ü son kullanma tarihi geçmiş veya bozulmuş ilaç olduğunu fark ettiğinde çöpe attıklarını belirterek akılcı olmayan ilaç kullanımı yaklaşımı göstermişlerdir. Katılımcıların \% 77,8'i sağlık ocağında hekimin yazdığı ilacı kabul ettiği ve yaşın artmasıyla bu oranın arttığı gözükmektedir. İlaç kullanan katılımcılar, kullanım talimatında en çok kullanım amacı kısmını okuduklarını belirtmişlerdir. Sağlık profesyoneline danışmadan reçetesiz olarak, katılımcıların \% 54,1'i en çok ağrı kesici ilacı, \% 19,2'si ise antibiyotik ilaç almaktadır. Katılımcıların sağlık profesyoneli ile muhatap olduğu durumlarda ilaç kullanımına daha akılcı yaklaştığı, bireysel kararların verildiği durumlarda ise akılcı olmayan bir yaklaşım sergilediklerini görmekteyiz. Bu konuda kişilerin muhatap bulabileceği danışma ofisleri veya çağrı servisleri ile akılcı yaklaşımın arttırılması ve eğitim müfredatlarında yer verilecek eğitimlerle ilaç kullanım bilincinin erken yaşta oluşturulmaya başlanması bu soruna çözüm olabilecektir.

Anahtar Kelimeler: Kapadokya bölgesi, akılcı ilaç kullanımı, ilaç kullanım alışkanlığı, yüz yüze anket.

\section{Determination of Drug Use Habits of the Residents of Cappadocia Region Provincial Centers}

\begin{abstract}
This study aims to determine the drug usage patterns and the factors affecting the aged 18 years and over in Nevsehir, Kayseri, Niğde, Aksaray and Kırşehir provincial centers in Cappadocia region. In our study, the Cappadocia region of over 18 years in the urban centers of the province with 686 people face to face survey method was applied. The results were evaluated as percent (\%) responses. $77.1 \%$ of the participants leave the medication lacking complaints, $65.3 \%$ of respondents, when the drug is past its expiration date or deteriorated noticed mentioned that they threw in the trash. This behavior is irrational drug use approach. Participants are to provide benefits seen previously used and drugs without a prescription from pharmacies more $77.8 \%$ of the participants in the health centers where doctors prescribed medications accepts and with increasing age seems to increase this rate. Participants who used medication stated that they read the most intended use part of the medicine in the prospectus. Without a medical consultation as nonprescription, $54.1 \%$ of participants had the most pain medication and $19.2 \%$ received antibiotics. Participants more rational approach to drug use where it is in contact with health professionals,we see that they exhibit if a nonrational approach in cases where the individual decisions. Increasing the rational approach with counseling offices or call services that people may find in this issue and starting to use medicine awareness at an early age with the trainings to be given in the education curriculum will be a solution to this problem.
\end{abstract}

Keywords: Cappadocia region, rational drug use, drug usage habit, face to face questionnaire

\footnotetext{
*e-mail: sonermete@nevsehir.edu.tr
} 


\section{Giriş}

1985 yılında Dünya Sağlık Örgütü (DSÖ)'nün Nairobi’de yaptığı toplantı Akılcı İlaç Kullanımı (AİK) çalışmaları için başlama noktası sayılmaktadır. DSÖ’nün 1985 Nairobi toplantısında AİK; "hastaların ilaçları klinik gereksinimlerine uygun biçimde, kişisel gereksinimlerini karşılayacak dozlarda, yeterli zaman diliminde, kendilerine ve topluma en düşük maliyette almaları için uyulması gereken kurallar bütünü” olarak tanımlamıştır [1].

Dünyada yanlış, gereksiz, etkisiz ve yüksek maliyetli ilaç kullanımı çeşitli boyutlarda sorunlara neden olabilmektedir. Bu sorunlar arasında hastalık ve ölüm oranlarında artış olması， ilaçların yan etki riskinin artması, kaynakların yanlış tüketilmesiyle sonuçta temel ilaçlara bile ulaşılabilirliğin azalması, acil ve temel ilaçlara karşı gelişebilecek dirence dayalı olarak, tedavinin ekonomik ve sosyal maliyetinin artması sayılabilir. Bu nedenlerden dolayı dünyada çeşitli çözüm yolları üretilmeye, geliştirilmeye çalışılmıştır. Bu bağlamda dünyada “Akılcı İlaç Kullanımı” çalışmaları başlatılmıştır [2].

Dünyada maliyeti yüksek, uygunsuz ve akılcı olmayan ilaç kullanımı ciddi bir sorundur ve ülkelerin sağlık harcamaları içinde önemli yer tutmaktadır. Türkiye, Hindistan vb. gibi gelişmekte olan ülkelerde yüksek maliyetli ve gereksiz ilaç kullanımı ülke ekonomisine ağır yük getirmektedir [3]. DSÖ, AİK ile ilgili, bir insanlık hakkı olarak sağlık ve sağlığa erişmekte eşitlik ilkesinden hareket ederek, ilaca erişebilirliğin uzun vadeli ilaç politikalarının ayrılmaz bir parçası olarak görülmesi gerektiği sonucuna varmıştır [2].

Akılcı ilaç kullanımı, ilaç tedavisinin etkili, güvenli ve ekonomik biçimde uygulanmasına olanak tanıyan planlama, yürütme ve izleme süreçlerinin tümünü kapsamaktadır. İlacın akılcı kullanımında temel yaklaşım; ilacın gerektiği zaman, gereken nitelikte, gerektiği kadar ve gerektiği biçimde kullanılmasıdır. $\mathrm{Bu}$ durum sağl1k hizmetlerinin örgütlenmesinden niteliğine kadar, hekimlerin ve toplumun eğitimi gibi birçok konuyla yakından bağlantılı olduğu ortadadır [4].

Ülkemizde ise Sağlık Bakanlığının yayımlamış olduğu 2014-2017 Stratejik Eylem Planında "Akılcı İlaç Kullanımını" birey ve toplumda incelemeyi ve sağlamayı hedefleyen stratejik planların yer alması, bu konunun günümüzde ve ilerleyen yıllarda ulaşılması planlanan hedef haline geldiğini göstermektedir [5].

DSÖ'nün de belirttiği gibi akılcı ilaç kullanımı her kesimi ilgilendiren, özellikle üzerinde durulması ve geliştirilmesi gereken bir konudur. Toplumun ilaç kullanma alışkanlıkları konusunda eğitimine destek olmak amacıyla kişilerin ilaç kullanım alışkanlıklarının saptanması oldukça önemlidir [6], [7].

Çalışmamızda, Kapadokya bölgesini oluşturan Nevşehir, Kırşehir, Niğde, Aksaray ve Kayseri illerinin şehir merkezlerinde yaşayan 18 ve üzeri bireylerin, ilaç kullanım alışkanlıklarının belirlenmesi, farkındalık yaratılması, ilaç kullanım davranışlarının incelenmesi ve bu davranışları etkileyen faktörlerin belirlenmesiyle Sağlık Bakanlığı'nın bölgesel eylem planlarına ve konuyla ilgili yapılacak olan diğer çalışmalara katkı sağlaması amaçlanmıştır. 


\section{Materyal ve Metot}

Epidemiyolojik araştırmalardan durum saptamaya yönelik tanımlayıcı bir araştırma olan çalışmamızda, Kapadokya bölgesinde bulunan; Nevşehir, Kırşehir, Niğde, Aksaray ve Kayseri illerinin şehir merkezlerinde yaşayan ve 18 yaş üzeri katılımcıların, ilaç kullanım alışkanlıklarını ve akılcı ilaç kullanım davranışlarını saptamak için birincil araştırma tekniklerinden olan anket yöntemi (yüz yüze) uygulanmıştır. Evren büyüklüğü 1.361.360 kişi olmakla birlikte, \% 5 hata payı ve \%99 güvenirlik seviyesinde, il merkez nüfuslarıyla orantılı olarak toplam 686 kişide anket uygulaması yapılmıştır. Anketin ilk bölümünde bulunan 7 soru demografik cevaplara yönelik, 7. sorudan itibaren ikinci bölümde yer alan sorular ise ilaç kullanım alışkanlığı ve farkındalık ölçmeye yönelik sorulardır.

Anket sorularına verilen cevaplar frekans (f) ve yüzde (\%) cevap olarak tablo biçimine dönüştürülmüştür. Sonuçlarımızı Kapadokya bölgesi ve bu bölgede yer alan iller bazında, demografik verilerle karşılaştırarak değerlendirdik. Bu yöntemi seçmemizdeki amacımız, ankete katılanların ilaç kullanım alışkanlıklarına dair bir profil analizini ortaya koymaktır.

\section{Bulgular}

Çalışma Kapadokya bölgesinin; Nevşehir, Kırşehir, Niğde, Aksaray ve Kayseri il merkezlerindeki 18 yaş ve üzeri kişileri kapsamaktadır. Katılımcı sayımızın 686 kişi olduğu çalışmamızın il bazındaki örneklem sayısı ile bazı sosyodemografik özelliklerinin dağılımı Tablo 1'de sunulmuştur.

Tablo 1. Katılımcıların il bazında sosyodemografik özelliklerinin dağılımı

\begin{tabular}{|c|c|c|c|c|c|c|c|c|c|c|c|c|c|}
\hline & & \multicolumn{2}{|c|}{ Nevşehir } & \multicolumn{2}{|c|}{ Kayseri } & \multicolumn{2}{|c|}{ Niğde } & \multicolumn{2}{|c|}{ Aksaray } & \multicolumn{2}{|c|}{ Kırşehir } & \multicolumn{2}{|c|}{ Toplam } \\
\hline & & $\mathbf{f}$ & $\%$ & $\mathbf{f}$ & $\%$ & f & $\%$ & $\mathbf{f}$ & $\%$ & f & $\%$ & f & $\%$ \\
\hline \multirow[t]{2}{*}{ Cinsiyet } & Kadın & 31 & 60,8 & 155 & 42,5 & 48 & 58,5 & 64 & 57,7 & 48 & 62,3 & 346 & 50,4 \\
\hline & Erkek & 20 & 39,2 & 210 & 57,5 & 34 & 41,5 & 47 & 42,3 & 29 & 37,7 & 340 & 49,6 \\
\hline \multirow[t]{4}{*}{ Yaş } & $18-24$ & 31 & 60,8 & 149 & 40,8 & 30 & 36,6 & 63 & 56,8 & 21 & 27,3 & 294 & 42,9 \\
\hline & $25-44$ & 17 & 33,3 & 131 & 35,9 & 35 & 42,7 & 33 & 29,7 & 30 & 39,0 & 246 & 35,9 \\
\hline & $45-64$ & 3 & 5,9 & 69 & 18,9 & 11 & 13,4 & 15 & 13,5 & 22 & 28,6 & 120 & 17,5 \\
\hline & 65 ve üstü & 0 & - & 16 & 4,4 & 6 & 7,3 & 0 & - & 4 & 5,2 & 26 & 3,8 \\
\hline \multirow[t]{2}{*}{ Medeni durum } & Evli & 14 & 27,5 & 187 & 51,2 & 47 & 57,3 & 38 & 34,2 & 51 & 66,2 & 337 & 49,1 \\
\hline & Bekar & 37 & 72,5 & 178 & 48,8 & 35 & 42,7 & 73 & 65,8 & 26 & 33,8 & 349 & 50,9 \\
\hline \multirow[t]{6}{*}{ Eğitim durumu } & Okur-Yazar Değil & 3 & 5,9 & 11 & 3,0 & 4 & 4,9 & 0 & - & 2 & 2,6 & 20 & 2,9 \\
\hline & Sadece Okur-Yazar & 2 & 3,9 & 21 & 5,8 & 4 & 4,9 & 1 & 0,9 & 2 & 2,6 & 30 & 4,4 \\
\hline & İlkokul & 5 & 9,8 & 51 & 14,0 & 9 & 11,0 & 11 & 9,9 & 9 & 11,7 & 85 & 12,4 \\
\hline & Ortaokul & 1 & 2,0 & 40 & 11,0 & 11 & 13,4 & 10 & 9,0 & 9 & 11,7 & 71 & 10,3 \\
\hline & Lise ve Dengi Okullar & 10 & 19,6 & 111 & 30,4 & 23 & 28,0 & 11 & 9,9 & 19 & 24,7 & 174 & 25,4 \\
\hline & Üniversite ve Üstü & 30 & 58,8 & 131 & 35,9 & 31 & 37,8 & 78 & 70,3 & 36 & 46,8 & 306 & 44,6 \\
\hline \multirow[t]{3}{*}{ Sosyal Güvence } & SGK & 37 & 72,5 & 302 & 82,7 & 63 & 76,8 & 93 & 83,8 & 69 & 89,6 & 564 & 82,2 \\
\hline & Özel Sağlık Sigorta Kurumları & 4 & 7,8 & 24 & 6,6 & 3 & 3,7 & 11 & 9,9 & 6 & 7,8 & 48 & 7,0 \\
\hline & Güvence yok & 10 & 19,6 & 39 & 10,7 & 16 & 19,5 & 7 & 6,3 & 2 & 2,6 & 74 & 10,8 \\
\hline \multirow[t]{4}{*}{ Aylık gelir } & 1000 TL'nin Altı & 33 & 64,7 & 122 & 33,4 & 26 & 31,7 & 46 & 41,4 & 28 & 36,4 & 255 & 37,2 \\
\hline & 1000-1335 TL Arası & 10 & 19,6 & 107 & 29,3 & 22 & 26,8 & 26 & 23,4 & 10 & 13,0 & 175 & 25,5 \\
\hline & 1336-2000 TL Aras1 & 5 & 9,8 & 83 & 22,7 & 18 & 22,0 & 13 & 11,7 & 17 & 22,1 & 136 & 19,8 \\
\hline & 2000 TL Üzeri & 3 & 5,9 & 53 & 14,5 & 16 & 19,5 & 26 & 23,4 & 22 & 28,6 & 120 & 17,5 \\
\hline
\end{tabular}


Tablo 2'de katılımcıların il bazında ve genel bazda ilaçlarını temin etme durumları sunulmuştur. 686 kişiye en çok iki cevap verme hakkı tanınmıştır. Toplamda 979 cevap verilmiş olup, sonuçlar il bazında incelendiğinde muayene sonrası reçeteli olarak sağlık güvencesiyle ilaç temin edenlerin yüzdeleri sırasıyla Nevşehir $(\% 72,5)$, Kayseri $(\% 63)$, Niğde $(\% 61)$, Aksaray $(\% 78,4)$ ve Kırşehir $(\% 76,6)$ olarak gözükmektedir. Hekime verilen numune ürünlerden temin etme yoluna giden katılımcıların il bazında yüzdelerinin; Nevşehir'de \%49, Kayseri'de \%28,8, Niğde’de \%28, Aksaray’da \%21,6 ve Kırşehir'de \%16,9 olduğunu görmekteyiz. Genel olarak sonuçlar incelendiğinde katılımcıların \% 67,5'i muayene sonrası reçeteli olarak sağlık güvencesiyle ilaç temin etme yoluna giderken, bu yoldan sonra en çok başvurulan ikinci temin şeklinin \% 27,7 oranında hekime verilen numune ürünlerden olduğunu görmekteyiz.

Tablo 2. Katılımcıların il bazında ve genel bazda ilaçlarını temin etme durumlarının dağılımı

\begin{tabular}{|c|c|c|c|c|c|}
\hline & & İlaçlarınızı genellikle & ereden/nasıl temin edersini & ? En çok iki cevap (\%) & \\
\hline & $\begin{array}{c}\text { Hekime verilen } \\
\text { numune ürünlerden } \\
\text { temin ederim }\end{array}$ & $\begin{array}{c}\text { Eczaneden reçetesiz } \\
\text { olarak paramla } \\
\text { alırım }\end{array}$ & $\begin{array}{c}\text { Muayene sonrası reçeteli } \\
\text { olarak sağlık güvencemle } \\
\text { alırım }\end{array}$ & $\begin{array}{c}\text { Tanıdık/komşu/arkadaştan } \\
\text { alırım }\end{array}$ & $\begin{array}{l}\text { Evdeki } \\
\text { ilaçlardan } \\
\text { kullanırım }\end{array}$ \\
\hline Nevşehir & 49,0 & 13,7 & 72,5 & 2,0 & 11,8 \\
\hline Kayseri & 28,8 & 16,7 & 63,0 & 8,5 & 24,4 \\
\hline Niğde & 28,0 & 15,9 & 61,0 & 9,8 & 29,3 \\
\hline Aksaray & 21,6 & 13,5 & 78,4 & 3,6 & 21,6 \\
\hline Kırşehir & 16,9 & 18,2 & 76,6 & 6,5 & 31,2 \\
\hline Tümü* & 27,7 & 16,0 & 67,5 & 7,1 & 24,3 \\
\hline
\end{tabular}

Tablo 3'te katılımcıların eğitim durumlarına göre ilaçları temin etme yollarına bakıldığında, okuryazar olmayan katılımcıların \%30’u muayene sonrası reçeteli olarak sağlık güvencesiyle ilaç temin etme yolunu seçerken, eğitim durumu üniversite ve üzeri olan katılımcılarda bu oranın \%76,1'e arttığı görülmektedir.

Tablo 3. Katılımcıların eğitim durumlarına göre ilaçları temin etme yolları

\begin{tabular}{|c|c|c|c|c|c|}
\hline & \multicolumn{5}{|c|}{ İlaçlarınızı genellikle nereden/nasıl temin edersiniz? En çok iki cevap (\%) } \\
\hline & $\begin{array}{l}\text { Hekime verilen } \\
\text { numune ürünlerden } \\
\text { temin ederim }\end{array}$ & $\begin{array}{c}\text { Eczaneden } \\
\text { reçetesiz olarak } \\
\text { paramla alırım }\end{array}$ & $\begin{array}{l}\text { Muayene sonrası } \\
\text { reçeteli olarak sağlık } \\
\text { güvencemle alırım }\end{array}$ & $\begin{array}{c}\text { Tanıdık/komşu/arkadaştan } \\
\text { alırım }\end{array}$ & $\begin{array}{c}\text { Evdeki } \\
\text { ilaçlardan } \\
\text { kullanırım }\end{array}$ \\
\hline Okur-Yazar Değil & 30,0 & 10,0 & 30,0 & 10,0 & 60,0 \\
\hline Sadece Okur-Yazar & 43,3 & 13,3 & 43,3 & 16,7 & 26,7 \\
\hline İlkokul & 23,5 & 21,2 & 63,5 & 7,1 & 30,6 \\
\hline Ortaokul & 26,8 & 7,0 & 66,2 & 7,0 & 28,2 \\
\hline Lise ve Dengi Okullar & 28,7 & 17,8 & 63,2 & 8,0 & 24,1 \\
\hline Üniversite ve Üstü & 26,8 & 16,3 & 76,1 & 5,6 & 19,3 \\
\hline Tümü* & 27,7 & 16,0 & 67,5 & 7,1 & 24,3 \\
\hline
\end{tabular}

Sosyal güvence durumunun, ilaç teminine etkisi incelendiğinde SGK güvencesi olan katılımcıların \% 71,8'i ve özel sağlık sigortası olanların \% 60,4'ü genellikle muayene sonrası reçeteli olarak sağlık güvencesiyle ilaç temin etme yoluna giderken, sosyal güvencesi olmayan kişilerin \% 
36,5 'nin hekime verilen numune ürünlerden, \% 25,7'sinin eczaneden reçetesiz olarak parasıyla aldığını görmekteyiz (Tablo 4).

Tablo 4. Katılımcıların sosyal güvence durumlarına göre ilaçları temin etme yollarının dağılımı

\begin{tabular}{|c|c|c|c|c|c|}
\hline & \multicolumn{5}{|c|}{ İlaçlarınızı genellikle nereden/nasıl temin edersiniz? En çok iki cevap (\%) } \\
\hline & $\begin{array}{l}\text { Hekime verilen } \\
\text { numune ürünlerden } \\
\text { temin ederim }\end{array}$ & $\begin{array}{c}\text { Eczaneden } \\
\text { reçetesiz olarak } \\
\text { paramla alırım }\end{array}$ & $\begin{array}{l}\text { Muayene sonrası } \\
\text { reçeteli olarak sağlık } \\
\text { güvencemle alırım }\end{array}$ & $\begin{array}{l}\text { Tanıdık/komşu/ } \\
\text { arkadaştan alırım }\end{array}$ & $\begin{array}{c}\text { Evdeki } \\
\text { ilaçlardan } \\
\text { kullanırım }\end{array}$ \\
\hline SGK & 27,0 & 14,2 & 71,8 & 6,2 & 23,9 \\
\hline Özel Sağlık Sigorta Kurumları & 22,9 & 22,9 & 60,4 & 12,5 & 35,4 \\
\hline Güvence Yok & 36,5 & 25,7 & 39,2 & 10,8 & 20,3 \\
\hline Tümü* & 27,7 & 16,0 & 67,5 & 7,1 & 24,3 \\
\hline
\end{tabular}

Katılımcıların \% 37,2'sinde gelir durumlarının $1000 \mathrm{TL}$ ve altında olduğunu görmekteyiz. Gelir durumu düştükçe eczaneden reçetesiz olarak bedeliyle ilaç temin etme yolunun azaldığını görmekteyiz. Tüm gelir gruplarında tercihler incelendiğine, genellikle muayene sonrası reçeteli olarak sağlık güvenceyle ilaç alımının tercih edildiği saptanmıştır (Tablo 5).

Tablo 5. Katılımcıların gelir durumlarına göre ilaçları temin etme yolları

\begin{tabular}{|c|c|c|c|c|c|}
\hline & \multicolumn{5}{|c|}{ İlaçlarınızı genellikle nereden/nasıl temin edersiniz? En çok iki cevap (\%) } \\
\hline & $\begin{array}{l}\text { Hekime verilen } \\
\text { numune ürünlerden } \\
\text { temin ederim }\end{array}$ & $\begin{array}{c}\text { Eczaneden } \\
\text { reçetesiz olarak } \\
\text { paramla alırım }\end{array}$ & $\begin{array}{l}\text { Muayene sonrası } \\
\text { reçeteli olarak sağlık } \\
\text { güvencemle alırım }\end{array}$ & $\begin{array}{l}\text { Tanıdık/komşu/ } \\
\text { arkadaştan alırım }\end{array}$ & $\begin{array}{c}\text { Evdeki } \\
\text { ilaçlardan } \\
\text { kullanırım }\end{array}$ \\
\hline 1000 TL'nin Altı & 30,2 & 14,5 & 63,1 & 8,2 & 20,8 \\
\hline 1000-1335 TL Aras1 & 26,3 & 16,0 & 68,6 & 9,7 & 25,1 \\
\hline 1336-2000 TL Aras1 & 27,9 & 18,4 & 68,4 & 5,9 & 23,5 \\
\hline 2000 TL Üzeri & 24,2 & 16,7 & 74,2 & 2,5 & 31,7 \\
\hline Tümü* & 27,7 & 16,0 & 67,5 & 7,1 & 24,3 \\
\hline
\end{tabular}

Katılımcıların il ve genel bazda ilaçlarını saklama yerlerini genellikle buzdolabı olarak tercih ettiklerini görmekteyiz (Tablo 6). Eğitim durumuna göre saklama yerleri incelendiğinde, eğitim seviyesi artıkça buzdolabında ve pencere kenarlarında saklama tercihinin azaldığı, ecza dolabında ve çekmecede/dolapta saklama tercihinde artış olduğu gözükmektedir (Tablo 7).

Tablo 6. Katılımcıların il ve genel bazda ilaçlarını saklama yerlerinin dağılımı

\begin{tabular}{|c|c|c|c|c|c|c|}
\hline & \multicolumn{6}{|c|}{ İlaçlarınızı genellikle nerede saklarsınız? Tek cevap (\%) } \\
\hline & $\begin{array}{c}\text { Ecza } \\
\text { dolabinda }\end{array}$ & Buzdolabında & $\begin{array}{l}\text { Çekmecede / } \\
\text { Dolapta }\end{array}$ & Balkonda & $\begin{array}{c}\text { Pencere } \\
\text { kenarlarında }\end{array}$ & $\begin{array}{l}\text { Isı koşullarına göre (yazın } \\
\text { buzdolab1/ kışın ecza dolabı) }\end{array}$ \\
\hline Nevşehir & 35,3 & 31,4 & 17,6 & - & - & 11,8 \\
\hline Kayseri & 24,1 & 40,8 & 25,8 & 0,5 & 0,8 & 24,4 \\
\hline Niğde & 18,3 & 34,1 & 34,1 & - & 3,7 & 29,3 \\
\hline Aksaray & 29,7 & 48,6 & 14,4 & - & - & 21,6 \\
\hline Kırşehir & 11,7 & 16,9 & 39,0 & - & 1,3 & 31,2 \\
\hline Tümü* & 23,8 & 37,9 & 25,8 & 0,3 & 1,0 & 24,3 \\
\hline
\end{tabular}


Mete S., Ünal Z.

Tablo 7. Katılımcıların il ve genel bazda ilaçlarını saklama yerlerinin eğitim durumuna göre dağılımı İlaçlarınızı genellikle nerede saklarsınız? Tek cevap (\%)

\begin{tabular}{|c|c|c|c|c|c|c|}
\hline & \multicolumn{6}{|c|}{ İlaçlarınızı genellikle nerede saklarsınız? Tek cevap (\%) } \\
\hline & $\begin{array}{c}\text { Ecza } \\
\text { dolabında }\end{array}$ & Buzdolabında & $\begin{array}{l}\text { Çekmecede } \\
\text { / Dolapta }\end{array}$ & Balkonda & $\begin{array}{c}\text { Pencere } \\
\text { kenarlarında }\end{array}$ & $\begin{array}{c}\text { Isı koşullarına göre } \\
\text { (yazın buzdolabı/ kışın } \\
\text { ecza dolabı) }\end{array}$ \\
\hline Okur-Yazar Değil & 5,0 & 40,0 & 35,0 & - & 20,0 & - \\
\hline Sadece Okur-Yazar & 20,0 & 53,3 & 23,3 & - & - & 3,3 \\
\hline İlkokul & 15,3 & 50,6 & 23,5 & - & - & 10,6 \\
\hline Ortaokul & 22,5 & 45,1 & 22,5 & - & 1,4 & 8,5 \\
\hline Lise ve Dengi Okullar & 23,6 & 35,1 & 25,9 & - & 0,6 & 14,9 \\
\hline Üniversite ve Üstü & 28,1 & 32,7 & 26,8 & 0,7 & 0,3 & 11,4 \\
\hline Tümü* & 23,8 & 37,9 & 25,8 & 0,3 & 1,0 & 11,2 \\
\hline
\end{tabular}

Prospektüs veya kullanma talimat bilgilerinin "saklama koşullarını" okuyan ve okumayan katılımcıların, ilaçları sakladıkları yerlere bakıldığında, okuyanların \% 24’ü 1sı koşullarına göre ilaçlarını saklarken, okumayanların \% 7,1'i saklamaktadır (Tablo 8).

Tablo 8. Prospektüs veya kullanma talimat bilgilerinin "saklama koşullarını" okuyan ve okumayan katılımcıların, ilaçları sakladıkları yerlere göre dağılımı

\begin{tabular}{|c|c|c|c|c|c|c|c|c|c|c|c|c|}
\hline & \multirow{2}{*}{\multicolumn{2}{|c|}{$\begin{array}{c}\text { Ecza } \\
\text { dolabında } \\
\text { Saklama } \\
\text { koşullarını } \\
\text { okuma }\end{array}$}} & \multicolumn{2}{|c|}{ Buzdolabında } & \multicolumn{2}{|c|}{$\begin{array}{c}\text { Çekmecede / } \\
\text { Dolapta }\end{array}$} & \multicolumn{2}{|c|}{ Balkonda } & \multicolumn{2}{|c|}{$\begin{array}{c}\text { Pencere } \\
\text { kenarlarında }\end{array}$} & \multicolumn{2}{|c|}{$\begin{array}{l}\text { Isı koşullarına } \\
\text { göre (yazın } \\
\text { buzdolabı / kışın } \\
\text { ecza dolabı) }\end{array}$} \\
\hline & & & $\begin{array}{r}\mathrm{Sa} \\
\mathrm{kos} \\
\mathrm{O}\end{array}$ & $\begin{array}{l}\text { ama } \\
\text { larını } \\
\text { ma }\end{array}$ & $\begin{array}{r}\mathrm{Sa} \\
\mathrm{koşl} \\
\mathrm{ol}\end{array}$ & $\begin{array}{l}\text { ama } \\
\text { larını } \\
\text { ma }\end{array}$ & $\begin{array}{r}\mathrm{Sa} \\
\mathrm{koş} \\
\mathrm{ol}\end{array}$ & $\begin{array}{l}\text { ma } \\
\text { arını } \\
\text { ma }\end{array}$ & $\begin{array}{r}\mathrm{Sa} \\
\mathrm{koş} \\
\mathrm{ol}\end{array}$ & $\begin{array}{l}\text { na } \\
\text { rinı } \\
\text { la }\end{array}$ & $\begin{array}{r}\mathrm{Sa} \\
\mathrm{koş} \\
\mathrm{ok}\end{array}$ & $\begin{array}{l}\text { ma } \\
\text { rinı } \\
\text { la }\end{array}$ \\
\hline & Evet & Hayır & Evet & Hayır & Evet & Hayır & Evet & Hayır & Evet & Hayır & Evet & Hayır \\
\hline Nevşehir & 71,4 & 29,5 & 14,3 & 34,1 & 14,3 & 18,2 & 0,0 & 0,0 & 0,0 & 0,0 & 0,0 & 18,2 \\
\hline Kayseri & 26,9 & 23,3 & 30,8 & 43,6 & 25,6 & 25,8 & 0,0 & 0,7 & 0,0 & 1,0 & 16,7 & 5,6 \\
\hline Niğde & 18,8 & 18,2 & 31,3 & 34,8 & 18,8 & 37,9 & 0,0 & 0,0 & 0,0 & 4,5 & 31,3 & 4,5 \\
\hline Aksaray & 30,0 & 29,6 & 50,0 & 48,1 & 13,3 & 14,8 & 0,0 & 0,0 & 0,0 & 0,0 & 6,7 & 7,4 \\
\hline Kırşehir & 5,6 & 17,1 & 2,8 & 29,3 & 36,1 & 41,5 & 0,0 & 0,0 & 0,0 & 2,4 & 55,6 & 9,8 \\
\hline Tümü* & 24,0 & 23,7 & 27,5 & 41,2 & 24,6 & 26,2 & 0,0 & 0,4 & 0,0 & 1,3 & 24,0 & 7,1 \\
\hline
\end{tabular}

Çalışmamızda katılımcıların \% 92,9'u ilaç hakkında bilgi almak için herhangi bir başvuruda bulunurken, \% 7,1'i bilgi almak için başvuru yapmamaktadır. İlaç hakkında bilgi almak için başvuru yapan katılımcıların ilk olarak \% 49'nun hekime, \% 18,1'nin eczacıya, \%16,9'nun prospektüs veya kullanma talimatını okuyarak bilgi edindiği sonucuna ulaşıııışıı (Tablo 9).

Tablo 9. Katılımcıların ilaç hakkında bilgi almak için yaptı̆̆ başvuruların il ve genel bazda dağılımı

\begin{tabular}{|c|c|c|c|c|c|c|c|c|}
\hline & & \multicolumn{6}{|c|}{ Başvururum (\%) } & \\
\hline & $\begin{array}{c}\text { Başvurmam } \\
(\%)\end{array}$ & Hekime & Eczaciya & Hemşireye & $\begin{array}{l}\text { İlacı daha } \\
\text { önce kullanan } \\
\text { tanıdıklara }\end{array}$ & $\begin{array}{c}\text { İnternetten } \\
\text { yararlanırım }\end{array}$ & $\begin{array}{c}\text { Prospektüsü / } \\
\text { Kullanım } \\
\text { Talimatını } \\
\text { okurum }\end{array}$ & $\begin{array}{c}\text { Başvururum } \\
(\%)\end{array}$ \\
\hline Nevşehir & 5,9 & 56,9 & 23,5 & - & 2,0 & - & 11,8 & 94,1 \\
\hline Kayseri & 9,0 & 47,7 & 18,6 & 2,7 & 3,3 & 1,9 & 16,7 & 91,0 \\
\hline Niğde & 7,3 & 42,7 & 15,9 & 2,4 & 3,7 & 3,7 & 24,4 & 92,7 \\
\hline Aksaray & 3,6 & 51,4 & 20,7 & 3,6 & 3,6 & 5,4 & 11,7 & 96,4 \\
\hline Kırşehir & 3,9 & 53,2 & 10,4 & 1,3 & 2,6 & 7,8 & 20,8 & 96,1 \\
\hline Tümü* & 7,1 & 49,0 & 18,1 & 2,5 & 3,2 & 3,2 & 16,9 & 92,9 \\
\hline
\end{tabular}


Eğitim seviyesinin ilaç hakkında bilgi almak için ilk olarak başvurulacak kişiye/yönteme etkisine bakıldığında, düşük eğitim seviyesinde ilacı daha önce kullanan tanıdıklara başvuru tercih edilirken, eğitim seviyesi arttıkça bu eğilimden uzaklaşıldığı fakat internetten bilgi alma tercihinin arttığını görmekteyiz (Tablo 10).

Tablo 10. Katılımcıların ilaç hakkında bilgi almak için yaptığı başvuruların eğitim seviyesine göre dağılımı

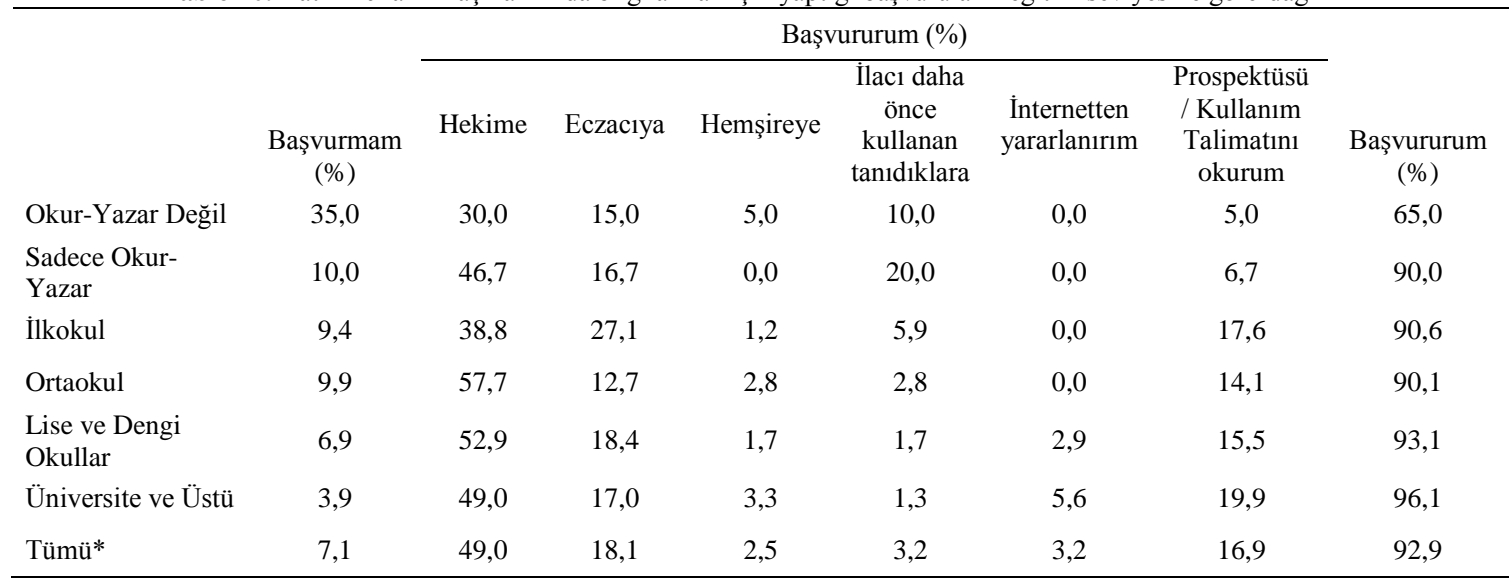

Kapadokya Bölgesi illeri genelinde cevaplar incelendiğinde, ilacı kullanırken istenmeyen bir etki görüldüğünde ilk olarak katılımcıların \% 93,6'sı herhangi bir kaynağa başvururken, \% 6,4'ü ise hiçbir başvuru yapmamaktadır. İlacı kullanırken istenmeyen bir etki ile karşılaştığında, katılımcıların ilk olarak \% 65'nin hekime, \%10,6'sının eczacıya, \%9,6'sının ilacın prospektüs veya kullanma talimatına başvurduğunu görmekteyiz (Tablo 11).

Tablo 11. Katılımcıların ilacı kullanırken istenmeyen bir etki görüldüğünde başvurduğu yerlerin il ve genel bazda dağılımı

\begin{tabular}{|c|c|c|c|c|c|c|c|c|}
\hline & \multirow[b]{2}{*}{$\begin{array}{c}\text { Başvurmam } \\
(\%)\end{array}$} & \multicolumn{6}{|c|}{ Başvururum (\%) } & \multirow[b]{2}{*}{$\begin{array}{c}\text { Başvururum } \\
(\%)\end{array}$} \\
\hline & & Hekime & Eczaciya & Hemşireye & $\begin{array}{l}\text { İlacı daha } \\
\text { önce } \\
\text { kullanan } \\
\text { tanıdıklara }\end{array}$ & $\begin{array}{c}\text { İnternetten } \\
\text { yararlanırım }\end{array}$ & $\begin{array}{l}\text { Prospektüsü } \\
\text { / Kullanım } \\
\text { Talimatını } \\
\text { okurum }\end{array}$ & \\
\hline Nevşehir & 5,9 & 82,4 & 2,0 & 3,9 & 0,0 & 3,9 & 2,0 & 94,1 \\
\hline Kayseri & 7,1 & 63,6 & 12,9 & 2,5 & 2,7 & 3,6 & 7,7 & 92,9 \\
\hline Niğde & 6,1 & 56,1 & 4,9 & 1,2 & 2,4 & 4,9 & 24,4 & 93,9 \\
\hline Aksaray & 3,6 & 69,4 & 15,3 & 0,0 & 0,9 & 4,5 & 6,3 & 96,4 \\
\hline Kırşehir & 7,8 & 63,6 & 5,2 & 0,0 & 2,6 & 7,8 & 13,0 & 92,2 \\
\hline Tümü* & 6,4 & 65,0 & 10,6 & 1,7 & 2,2 & 4,4 & 9,6 & 93,6 \\
\hline
\end{tabular}

Eğitim seviyelerine göre katılımcıların ilacı kullanırken istenmeyen bir etki görüldüğünde başvurduğu kaynakların dağılımına bakıldığında ise, eğitim seviyesindeki artışın ilk olarak hekime başvuruyu arttırdığını söyleyebiliriz. Düşük eğitim seviyedeki katılımcıların başvuru kaynağı, hekimden sonra ilacı daha önce kullanan tanıdıklara başvuru olarak şekillendiğini görmekteyiz (Tablo 12). 
Mete S., Ünal Z.

Tablo 12. Katılımcıların ilacı kullanırken istenmeyen bir etki görüldüğünde başvurduğu yerlerin eğitim seviyesine göre dağılımı

\begin{tabular}{|c|c|c|c|c|c|c|c|c|}
\hline & & \multicolumn{6}{|c|}{ Başvururum (\%) } & \\
\hline & $\begin{array}{c}\text { Başvurmam } \\
(\%)\end{array}$ & Hekime & Eczaciya & Hemşireye & $\begin{array}{l}\text { İlacı daha } \\
\text { önce } \\
\text { kullanan } \\
\text { tanıdıklara }\end{array}$ & $\begin{array}{c}\text { İnternetten } \\
\text { yararlanırım }\end{array}$ & $\begin{array}{l}\text { Prospektüsü } \\
\text { / Kullanım } \\
\text { Talimatını } \\
\text { okurum }\end{array}$ & $\begin{array}{c}\text { Başvururum } \\
(\%)\end{array}$ \\
\hline Okur-Yazar Değil & 15,0 & 50,0 & 10,0 & 5,0 & 20,0 & 0,0 & 0,0 & 85,0 \\
\hline $\begin{array}{l}\text { Sadece Okur- } \\
\text { Yazar }\end{array}$ & 10,0 & 56,7 & 13,3 & 0,0 & 13,3 & 3,3 & 3,3 & 90,0 \\
\hline İlkokul & 8,2 & 64,7 & 16,5 & 1,2 & 4,7 & 2,4 & 2,4 & 91,8 \\
\hline Ortaokul & 8,5 & 74,6 & 7,0 & 0,0 & 1,4 & 1,4 & 7,0 & 91,5 \\
\hline $\begin{array}{l}\text { Lise ve Dengi } \\
\text { Okullar }\end{array}$ & 6,3 & 57,5 & 14,4 & 1,1 & 0,6 & 5,2 & 14,9 & 93,7 \\
\hline Üniversite ve Üstü & 4,6 & 69,0 & 7,5 & 2,6 & 0,3 & 5,6 & 10,5 & 95,4 \\
\hline Tümü* & 6,4 & 65,0 & 10,6 & 1,7 & 2,2 & 4,4 & 9,6 & 93,6 \\
\hline
\end{tabular}

Katılımcılardan prospektüs veya kullanma talimatı bilgilerinin yan etkiler bölümünü okuyanların \% 69,6’sı istenmeyen bir etki görüldüğünde ilk olarak hekime başvururken, bu bölümü okumayanların ise \%59,6’sının hekime başvurduğu görülmektedir. Yan etkiler bölümünü okuyanların istenmeyen bir etki görüldüğünde okumayanlara göre eczacıya başvuruyu azalttığını sonuçlarımızdan söyleyebiliriz (Tablo $13)$.

Tablo 13. Katılımcılardan, prospektüs veya kullanma talimat bilgilerinin "Yan Etkiler" bölümünü okuyanların ve okumayanların ilacı kullanırken istenmeyen bir etki görüldüğünde başvurduğu yerlerin il ve genel bazda dağılımı

\begin{tabular}{|c|c|c|c|c|c|c|c|c|c|c|c|c|c|c|}
\hline & \multirow{2}{*}{\multicolumn{2}{|c|}{$\begin{array}{l}\text { Başvurmam } \\
\text { Yan etkileri } \\
\text { okuma }\end{array}$}} & \multicolumn{2}{|c|}{ Hekime } & \multicolumn{2}{|c|}{ Eczaciya } & \multicolumn{2}{|c|}{ Hemşireye } & \multicolumn{2}{|c|}{$\begin{array}{l}\text { İlacı daha önce } \\
\text { kullanan } \\
\text { tanıdıklara }\end{array}$} & \multicolumn{2}{|c|}{$\begin{array}{l}\text { İnternetten } \\
\text { yararlanırım }\end{array}$} & \multicolumn{2}{|c|}{$\begin{array}{c}\text { Prospektüsü / } \\
\text { Kullanma } \\
\text { talimatını } \\
\text { okurum }\end{array}$} \\
\hline & & & $\begin{array}{r}\text { Yan } \\
\text { ok }\end{array}$ & $\begin{array}{l}\text { kileri } \\
\text { ma }\end{array}$ & $\begin{array}{r}\text { Yan } \\
\text { ok }\end{array}$ & $\begin{array}{l}\text { kileri } \\
\text { ma }\end{array}$ & $\begin{array}{r}\text { Yan } \\
\text { ok }\end{array}$ & $\begin{array}{l}\text { kileri } \\
\text { ma }\end{array}$ & Yar & $\begin{array}{l}\text { kileri } \\
\text { ma }\end{array}$ & $\begin{array}{r}\text { Yan } \\
\text { ok }\end{array}$ & $\begin{array}{l}\text { kileri } \\
\text { ma }\end{array}$ & $\begin{array}{r}\text { Yan } \\
\text { ol }\end{array}$ & $\begin{array}{l}\text { tkileri } \\
\text { ma }\end{array}$ \\
\hline & Evet & Hayır & Evet & Hayır & Evet & Hayır & Evet & Hayır & Evet & Hayır & Evet & Hayır & Evet & Hayır \\
\hline Nevşehir & 3,8 & 8,0 & 84,6 & 80,0 & 3,8 & 0,0 & 0,0 & 8,0 & 0,0 & 0,0 & 3,8 & 4,0 & 3,8 & 0,0 \\
\hline Kayseri & 4,6 & 10,1 & 64,3 & 62,7 & 10,2 & 16,0 & 2,0 & 3,0 & 2,0 & 3,6 & 4,1 & 3,0 & 12,8 & 1,8 \\
\hline Niğde & 0,0 & 10,2 & 69,7 & 46,9 & 6,1 & 4,1 & 0,0 & 2,0 & 0,0 & 4,1 & 12,1 & 0,0 & 12,1 & 32,7 \\
\hline Aksaray & 1,8 & 5,6 & 80,7 & 57,4 & 7,0 & 24,1 & 0,0 & 0,0 & 0,0 & 1,9 & 3,5 & 5,6 & 7,0 & 5,6 \\
\hline Kırşehir & 5,3 & 15,0 & 70,2 & 45,0 & 5,3 & 5,0 & 0,0 & 0,0 & 0,0 & 10,0 & 5,3 & 15,0 & 14,0 & 10,0 \\
\hline Tümü* & 3,8 & 9,5 & 69,6 & 59,6 & 8,1 & 13,6 & 1,1 & 2,5 & 1,1 & 3,5 & 4,9 & 3,8 & 11,4 & 7,6 \\
\hline
\end{tabular}

Eğitim seviyelerine göre katılımcıların tedaviden sonra ellerinde fazla kalan ilaçları çoğunlukla ne yaptıklarına bakıldığında, tüm eğitim seviyelerinde çoğunlukla yapılan fazladan kalan ilacı evde sakladıkları, düşük eğitim seviyelerinde farklı olarak, elde kalan fazla ilacı tanıdıklara verme eğiliminin yüksek eğitim seviyelerine göre daha çok tercih edildiği görülmektedir (Tablo 14). 
Nevşehir Bilim ve Teknoloji Dergisi Cilt 6(2) 661-680 2017

Tablo 14. Katılımcıların tedaviden sonra elinde fazladan kalan ilaçları çoğunlukla ne yaptığının eğitim düzeyine göre dağılımı

Tedaviden sonra elinizde fazladan ilaç kaldığında çoğunlukla ne yaparsınız? Tek cevap (\%)

\begin{tabular}{|c|c|c|c|c|c|c|c|}
\hline & $\begin{array}{c}\text { Evde } \\
\text { saklarım }\end{array}$ & $\begin{array}{c}\text { Tanıdiklara } \\
\text { veririm }\end{array}$ & $\begin{array}{l}\text { Çöpe } \\
\text { atarım }\end{array}$ & $\begin{array}{c}\text { Lavaboya / } \\
\text { Tuvalete } \\
\text { dökerim }\end{array}$ & $\begin{array}{l}\text { Hastaneye } \\
\text { götürürüm }\end{array}$ & $\begin{array}{l}\text { Sağlık ocağına } \\
\text { götürürüm }\end{array}$ & $\begin{array}{l}\text { Eczaneye } \\
\text { götürürüm }\end{array}$ \\
\hline Okur-Yazar Değil & 65,0 & 10,0 & 20,0 & - & - & 5,0 & - \\
\hline Sadece Okur-Yazar & 70,0 & 3,3 & 13,3 & - & 6,7 & 3,3 & 3,3 \\
\hline İlkokul & 48,2 & 10,6 & 25,9 & - & 1,2 & 12,9 & 1,2 \\
\hline Ortaokul & 59,2 & 5,6 & 21,1 & 1,4 & 1,4 & 5,6 & 5,6 \\
\hline Lise ve Dengi Okullar & 59,2 & 5,2 & 17,8 & 1,1 & 4,6 & 6,9 & 5,2 \\
\hline Üniversite ve Üstü & 51,3 & 4,6 & 25,2 & 2,3 & 3,9 & 6,2 & 6,5 \\
\hline Tümü* & 55,0 & 5,7 & 22,3 & 1,5 & 3,5 & 7,0 & 5,1 \\
\hline
\end{tabular}

Katılımcılara ilaç kullanmayı hangi durumlarda bıraktıklarını sorduğumuzda, \% 71,1'i şikayetleri azaldığında veya bittiğinde, \% 72'si hekim tavsiyesine göre, \% 71,9'u hekimin önerdiği süre bitince, \% 49,4'ü faydası olmadığını düşündüğünde, \% 67,8'i yan etkileri olduğunu fark ettiğinde, \% 26,4'ü ilacın tadını veya kokusunu beğenmediğinde, \% 41,3'ü ilacı kullanmakta zorluk çektiğinde ve \% 69,1'i ilacın son kullanma tarihinin geçtĭgini fark ettiğinde ilacı kullanmayı bıraktıkları cevabını vermişleridir (Tablo 15).

Tablo 15. Katılımcıların ilaçları kullanmayı hangi durumlarda bıraktığının il ve genel bazda dağılımı

\begin{tabular}{|c|c|c|c|c|c|c|c|c|c|c|c|c|c|c|c|c|}
\hline & \multicolumn{16}{|c|}{ Hangi durumlarda ilaç kullanmayı bırakırsınız? Evet=E, Hayır=H } \\
\hline & \multicolumn{2}{|c|}{$\begin{array}{l}\text { Şikayetlerim } \\
\text { azaldığında } \\
\text { veya } \\
\text { bittiğinde }\end{array}$} & \multicolumn{2}{|c|}{$\begin{array}{l}\text { Hekim } \\
\text { tavsiyesine } \\
\text { göre }\end{array}$} & \multicolumn{2}{|c|}{$\begin{array}{l}\text { Hekimin } \\
\text { önerdiği süre } \\
\text { bitince }\end{array}$} & \multicolumn{2}{|c|}{$\begin{array}{l}\text { Faydası } \\
\text { olmadığını } \\
\text { düşünme }\end{array}$} & \multicolumn{2}{|c|}{$\begin{array}{l}\text { Yan etkileri } \\
\text { olduğunu } \\
\text { fark } \\
\text { ettiğimde }\end{array}$} & \multicolumn{2}{|c|}{$\begin{array}{l}\text { İlacın tadını/ } \\
\text { kokusunu } \\
\text { beğenmeme }\end{array}$} & \multicolumn{2}{|c|}{$\begin{array}{c}\text { İlacı } \\
\text { kullanmakta } \\
\text { zorluk } \\
\text { çektiğimde }\end{array}$} & \multicolumn{2}{|c|}{$\begin{array}{l}\text { Son } \\
\text { kullanma } \\
\text { tarihinin } \\
\text { geçtiğini } \\
\text { fark } \\
\text { ettiğimde }\end{array}$} \\
\hline & E & $\mathrm{H}$ & E & $\mathrm{H}$ & E & $\mathrm{H}$ & E & $\mathrm{H}$ & E & $\mathrm{H}$ & E & $\mathrm{H}$ & E & $\mathrm{H}$ & E & $\mathrm{H}$ \\
\hline Nevşehir & 92,2 & 7,8 & 90,2 & 9,8 & 94,1 & 5,9 & 56,9 & 43,1 & 70,6 & 29,4 & 45,1 & 54,9 & 58,8 & 41,2 & 68,6 & 31,4 \\
\hline Kayseri & 76,4 & 23,6 & 73,2 & 26,8 & 71,8 & 28,2 & 53,4 & 46,6 & 71,5 & 28,5 & 27,7 & 72,3 & 45,8 & 54,2 & 71,0 & 29,0 \\
\hline Niğde & 82,9 & 17,1 & 72,0 & 28,0 & 69,5 & 30,5 & 54,9 & 45,1 & 81,7 & 18,3 & 31,7 & 68,3 & 51,2 & 48,8 & 81,7 & 18,3 \\
\hline Aksaray & 75,7 & 24,3 & 62,2 & 37,8 & 60,4 & 39,6 & 42,3 & 57,7 & 45,9 & 54,1 & 13,5 & 86,5 & 25,2 & 74,8 & 51,4 & 48,6 \\
\hline Kırşehir & 66,2 & 33,8 & 68,8 & 31,2 & 76,6 & 23,4 & 29,9 & 70,1 & 64,9 & 35,1 & 20,8 & 79,2 & 20,8 & 79,2 & 72,7 & 27,3 \\
\hline Tümü* & 77,1 & 22,9 & 72,0 & 28,0 & 71,9 & 28,1 & 49,4 & 50,6 & 67,8 & 32,2 & 26,4 & 73,6 & 41,3 & 58,7 & 69,1 & 30,9 \\
\hline
\end{tabular}

Çalışmamızda Kapadokya bölgesinde bulunan il merkezlerinde yaşayanlara evlerinde son kullanma tarihi geçmiş veya bozulmuş ilaçları fark ettiklerinde genellikle ne yaptıklarını sorduğumuzda, bölge genelinde katılımcıların \% 65,3'ü çöpe attıklarını, \%11,8'i evde sakladığını, \% 8'i lavaboya veya tuvalete döktüklerini, \% 3,8'i hastaneye, \% 5,1'i sağlık ocağına ve \% 5,2'si eczaneye götürdüğü cevabını vermişleridir. Katılımcıların \% 0,7'si ise son kullanma tarihi geçmiş veya bozulmuş ilacı fark ettiğinde ise ilacı kullanmaya devam ettiğini söylemişlerdir (Tablo 16). 
Mete S., Ünal Z.

Tablo 16. Katılımcıların evlerinde son kullanma tarihi geçmiş veya bozulmuş ilaç olduğunu fark ettiğinde genellikle ne yaptığının il

\begin{tabular}{|c|c|c|c|c|c|c|c|}
\hline & \multicolumn{7}{|c|}{$\begin{array}{c}\text { Evinizde son kullanma tarihi geçmiş veya bozulmuş ilaç olduğunu fark ettiğinizde genellikle ne yaparsınız? Tek } \\
\text { cevap }(\%)\end{array}$} \\
\hline & $\begin{array}{l}\text { Evde } \\
\text { saklarim }\end{array}$ & $\begin{array}{l}\text { Çöpe } \\
\text { atarım }\end{array}$ & $\begin{array}{l}\text { Lavaboya / } \\
\text { Tuvalete dökerim }\end{array}$ & $\begin{array}{l}\text { Hastaneye } \\
\text { götürürüm }\end{array}$ & $\begin{array}{l}\text { Sağlık ocağına } \\
\text { götürürüm }\end{array}$ & $\begin{array}{l}\text { Eczaneye } \\
\text { götürürüm }\end{array}$ & $\begin{array}{c}\text { Kullanmaya } \\
\text { devam ederim }\end{array}$ \\
\hline Nevşehir & 21,6 & 62,7 & 5,9 & 2,0 & 2,0 & 5,9 & - \\
\hline Kayseri & 14,8 & 56,7 & 7,9 & 5,8 & 6,8 & 7,4 & 0,5 \\
\hline Niğde & 12,2 & 68,3 & 12,2 & 2,4 & - & 2,4 & 2,4 \\
\hline Aksaray & 4,5 & 84,7 & 5,4 & 0,9 & 0,9 & 2,7 & 0,9 \\
\hline Kırşehir & 1,3 & 76,6 & 9,1 & 1,3 & 10,4 & 1,3 & - \\
\hline Tümü* & 11,8 & 65,3 & 8,0 & 3,8 & 5,1 & 5,2 & 0,7 \\
\hline
\end{tabular}

Rahatsızlandıklarında ilk olarak ne yaptıklarını saptamaya yönelik sorumuzda, katılımcıların \% 64'ü ilk olarak muayene olmaya sağlık kuruluşuna gitmeyi tercih ederek akılcı bir yaklaşım sergilediğini görmekteyiz. Sonuçlarımıza göre katılımcılar sırasıyla \% 14,6'sının evdeki ilaçlarla tedavisini yapmayı, \% 8'nin rahatsızlığının geçmesini beklediğini, \% 5,7'sinin ilaç içermeyen tedavilere yönlendiğini, \% 4,4'nün komşu veya tanıdık tavsiyesi aldığını, \% 2,2'sinin internette araştırma yaparak tedavisine karar verdiğini ve \% 1,2'sinin ise eczacıya danışma yolunu tercih ettiklerini görmekteyiz (Tablo 17).

Tablo 17. Katılımcıların rahatsızlandıklarında ilk olarak ne yaptığının il ve genel bazda dağılımı

\begin{tabular}{|c|c|c|c|c|c|c|c|}
\hline & \multicolumn{7}{|c|}{ Rahatsızlandığınız zaman ilk olarak ne yaparsınız? Tek cevap (\%) } \\
\hline & $\begin{array}{l}\text { Muayene } \\
\text { olmak için } \\
\text { sağlık } \\
\text { kuruluşuna } \\
\text { giderim }\end{array}$ & $\begin{array}{c}\text { Komşu /Tanıdık } \\
\text { tavsiyesi alırım }\end{array}$ & $\begin{array}{c}\text { İnternette } \\
\text { araştırma } \\
\text { yaparak } \\
\text { tedavime karar } \\
\text { veririm }\end{array}$ & $\begin{array}{c}\text { Evdeki } \\
\text { ilaçlarla } \\
\text { tedavimi } \\
\text { yapmaya } \\
\text { çalışırım }\end{array}$ & $\begin{array}{c}\text { İlaç içermeyen } \\
\text { tedavilere } \\
\text { yönelirim(bitkisel, } \\
\text { diğer alternatif } \\
\text { tedaviler) }\end{array}$ & $\begin{array}{l}\text { Eczacıya } \\
\text { danışırım }\end{array}$ & $\begin{array}{c}\text { Geçmesini } \\
\text { beklerim }\end{array}$ \\
\hline Nevşehir & 84,3 & 3,9 & - & 3,9 & - & 3,9 & 3,9 \\
\hline Kayseri & 63,3 & 4,4 & 1,9 & 16,7 & 6,3 & 1,4 & 6,0 \\
\hline Niğde & 57,3 & 3,7 & 2,4 & 19,5 & 7,3 & - & 9,8 \\
\hline Aksaray & 60,4 & 6,3 & 3,6 & 15,3 & 5,4 & - & 9,0 \\
\hline Kırşehir & 66,2 & 2,6 & 2,6 & 5,2 & 5,2 & 1,3 & 16,9 \\
\hline Tümü* & 64,0 & 4,4 & 2,2 & 14,6 & 5,7 & 1,2 & 8,0 \\
\hline
\end{tabular}

Tüm eğitim düzeylerindeki katılımcılar, rahatsızlandıklarında ilk olarak muayene olmak için sağlık kuruluşlarına gitmeyi tercih ettiklerini, eğitim seviyesinin artmasıyla birlikte internetten faydalanmanın ve ilaç içermeyen tedavilere yönlenmenin arttı̆̆ını görmekteyiz (Tabloda gösterilmemiştir).

Evde kullanılmayan ilaçların bulunmasının hangi durumdan/durumlardan kaynaklandığını tespit etmeye çalıştığımız farkındalık sorumuzda, katılımcıların \% 51,5’i lazım olur diye ilaç aldığından, \% 54,7'si ilaçların son kullanma tarihlerinin geçtiğinin farkına varmadığından, \% 70,1'i iyileştiğini hissettiği anda ilacı kullanmayı bıraktığından, \% 58,5'i ilacın yan etkilerini gördüğünde tedaviyi bıraktığından dolayı kaynaklandığını söylememiz mümkündür (Tablo 18). 
Nevşehir Bilim ve Teknoloji Dergisi Cilt 6(2) 661-680 2017

Tablo 18. Katılımcılara göre evde kullanılmayan ilaçların bulunmasının il ve genel bazda kaynaklarına göre dağılımı Sizce, evde kullanılmayan ilaçların bulunması hangi durumdan/durumlardan kaynaklanır? Evet=E, Hayır=H

\begin{tabular}{|c|c|c|c|c|c|c|c|c|c|c|c|c|c|c|c|c|}
\hline & \multicolumn{2}{|c|}{$\begin{array}{l}\text { Lazım olur } \\
\text { diye ilaç } \\
\text { aldığımdan }\end{array}$} & \multicolumn{2}{|c|}{$\begin{array}{l}\text { İlaçların son } \\
\text { kullanma } \\
\text { tarihlerinin } \\
\text { geçtiğinin } \\
\text { farkına } \\
\text { vardığımdan }\end{array}$} & \multicolumn{2}{|c|}{$\begin{array}{l}\text { İyileşme } \\
\text { hissettiğim } \\
\text { de ilacı } \\
\text { bıraktığım } \\
\text { dan }\end{array}$} & \multicolumn{2}{|c|}{$\begin{array}{l}\text { Tanıdık } \\
\text { tavsiyesi } \\
\text { üzerine } \\
\text { reçetesiz } \\
\text { ilaç } \\
\text { aldığımdan }\end{array}$} & \multicolumn{2}{|c|}{$\begin{array}{l}\text { İlacın yan } \\
\text { etkilerini } \\
\text { gördüğüm } \\
\text { de tedaviyi } \\
\text { bıraktığım } \\
\text { dan }\end{array}$} & \multicolumn{2}{|c|}{$\begin{array}{c}\text { Hekim ilacı } \\
\text { değiştirdiği } \\
\text { nde ilacı } \\
\text { kullanmak } \\
\text { istemediği } \\
\text { mden }\end{array}$} & \multicolumn{2}{|c|}{$\begin{array}{c}\text { İlacı } \\
\text { kullanmada } \\
\text { zorluk } \\
\text { çektiğimde } \\
\text { tedaviyi } \\
\text { bıraktığımda }\end{array}$} & \multicolumn{2}{|c|}{$\begin{array}{l}\text { İlaca karşı } \\
\text { önyargım } \\
\text { oluştuğunda } \\
\text { tedaviyi } \\
\text { bıraktığımdan }\end{array}$} \\
\hline & $\mathrm{E}$ & $\mathrm{H}$ & E & $\mathrm{H}$ & E & $\mathrm{H}$ & $\mathrm{E}$ & $\mathrm{H}$ & E & $\mathrm{H}$ & $\mathrm{E}$ & $\mathrm{H}$ & $\mathrm{E}$ & $\mathrm{H}$ & E & $\mathrm{H}$ \\
\hline evş & 80,4 & 19,6 & 39,2 & 60,8 & 64,7 & 35,3 & 37,3 & 62,7 & 68,6 & 31,4 & 39,2 & 60,8 & 51,0 & 49,0 & 45,1 & 54,9 \\
\hline ayseri & 50,4 & 49,6 & 58,1 & 41,9 & 69,9 & 30,1 & 31,2 & 68,8 & 61,6 & 38,4 & 55,6 & 44,4 & 47,1 & 52,9 & 34,2 & 65,8 \\
\hline iğgde & 68,3 & 31,7 & 53,7 & 46,3 & 78,0 & 22,0 & 31,7 & 68,3 & 63,4 & 36,6 & 53,7 & 46,3 & 52,4 & 47,6 & 52,4 & 47,6 \\
\hline ksaray & 41,4 & 58,6 & 50,5 & 49,5 & 66,7 & 33,3 & 24,3 & 75,7 & 45,9 & 54,1 & 25,2 & 74,8 & 28,8 & 71,2 & 36,9 & 63,1 \\
\hline Kırşehir & 33,8 & 66,2 & 55,8 & 44,2 & 71,4 & 28,6 & 5,2 & 94,8 & 49,4 & 50,6 & 41,6 & 58,4 & 22,1 & 77,9 & 19,5 & 80,5 \\
\hline Tümü* & 51,5 & 48,5 & 54,7 & 45,3 & 70,1 & 29,9 & 27,7 & 72,3 & 58,5 & 41,5 & 47,7 & 52,3 & 42,3 & 57,7 & 36,0 & 64,0 \\
\hline
\end{tabular}

Çalışmamızda eczaneden reçetesiz ilaç alma durumlarını ve alıyorsa tercihlerini neye göre belirlediğine baktığımızda, katılımcıların \% 36,6'sı reçetesiz ilaç almıyorken, \% 63,4'ü almaktadır. Reçetesiz ilaç alan katılımcılara nedenleri için en çok iki cevap hakkı sunulduğunda, cevapların $\% 65,1$ ' $\mathrm{i}$ önceden kullanıp faydasını gördüğü ilacı göre, \% 32,2'sinin tercihlerini muayenelerde hekimin yazdığı ilaçlara göre belirlediğinden oluştuğunu görmekteyiz (Tablo 19).

Tablo 19. Katılımcıların eczaneden reçetesiz ilaç alma durumlarında tercihlerinin il ve genel bazda dağılımı

\begin{tabular}{|c|c|c|c|c|c|c|c|c|}
\hline \multirow[b]{4}{*}{ Nevşehir } & \multicolumn{8}{|c|}{ Eczaneden reçetesiz ilaç alıyorsanız bu ilaçları daha çok neye göre tercih edersiniz? En çok iki cevap (\%) } \\
\hline & \multirow{2}{*}{$\begin{array}{c}\text { Almiyorum } \\
(\%)\end{array}$} & $\begin{array}{c}\text { Daha önce kullanıp } \\
\text { faydasını gördüğ̈um } \\
\text { ilaca göre }\end{array}$ & $\begin{array}{c}\text { Eczacinın } \\
\text { tavsiyesine } \\
\text { göre }\end{array}$ & $\begin{array}{l}\text { Muayenelerde } \\
\text { hekimin } \\
\text { yazdığı } \\
\text { ilaçlara göre }\end{array}$ & $\begin{array}{l}\text { Tanıdık } \\
\text { tavsiyesine } \\
\text { göre }\end{array}$ & $\begin{array}{l}\text { Danıştığım } \\
\text { hekimin } \\
\text { tavsiyesine } \\
\text { göre }\end{array}$ & $\begin{array}{c}\text { Fiyatına } \\
\text { göre }\end{array}$ & \multirow{2}{*}{$\begin{array}{l}\text { Aliyorum } \\
(\%)\end{array}$} \\
\hline & & & & Alıyorum $(\%)$ & & & & \\
\hline & 58,8 & 76,2 & 9,5 & 23,8 & 4,8 & 14,3 & 9,5 & 41,2 \\
\hline Kayseri & 37,3 & 62,9 & 26,6 & 30,1 & 10,0 & 19,2 & 6,1 & 62,7 \\
\hline Niğde & 34,1 & 68,5 & 18,5 & 22,2 & 16,7 & 11,1 & 11,1 & 65,9 \\
\hline Aksaray & 36,0 & 63,4 & 22,5 & 35,2 & 7,0 & 12,7 & - & 64,0 \\
\hline Kırşehir & 22,1 & 68,3 & 15,0 & 48,3 & 3,3 & 16,7 & 15,0 & 77,9 \\
\hline Tümü* & 36,6 & 65,1 & 22,5 & 32,2 & 9,2 & 16,6 & 7,1 & 63,4 \\
\hline
\end{tabular}

Eğitim düzeylerine göre katılımcıların eczaneden reçetesiz ilaç alımlarında tercihlerinin nasıl değiştiğine bakıldığında, üniversite ve üstü eğitim düzeyine sahip katılımcıların \% 38,2'si reçetesiz ilaç almama eğilimine en çok sahip grubu oluştururken, üniversite ve üstü eğitim düzeyine sahip reçetesiz ilaç alan katılımcıların \% 65,1'i daha önce kullanıp fayda gördüğü ilaçları tercih ettiğini görmekteyiz (Tablo 20). 
Mete S., Ünal Z.

Tablo 20. Katılımcıların eczaneden reçetesiz ilaç alma durumlarında tercihlerinin eğitim düzeyinde dağılımı Eczaneden reçetesiz ilaç alıyorsanız bu ilaçları daha çok neye göre tercih edersiniz? En çok iki cevap

$(\%)$

\begin{tabular}{|c|c|c|c|c|c|c|c|c|}
\hline & $\begin{array}{c}\text { Almiyorum } \\
(\%)\end{array}$ & $\begin{array}{l}\text { Daha önce } \\
\text { kullanıp } \\
\text { faydasını } \\
\text { gördüğüm } \\
\text { ilaca göre }\end{array}$ & $\begin{array}{c}\text { Eczacinın } \\
\text { tavsiyesine } \\
\text { göre }\end{array}$ & $\begin{array}{c}\text { Muayeneler } \\
\text { de hekimin } \\
\text { yazdığı } \\
\text { ilaçlara } \\
\text { göre } \\
\text { Alıyorun }\end{array}$ & $\begin{array}{l}\text { Tanıdık } \\
\text { tavsiyesine } \\
\text { göre } \\
(\%) \\
\end{array}$ & $\begin{array}{l}\text { Danıştı̆̆ım } \\
\text { hekimin } \\
\text { tavsiyesine } \\
\text { göre }\end{array}$ & $\begin{array}{l}\text { Fiyatina } \\
\text { göre }\end{array}$ & $\begin{array}{c}\text { Aliyorum } \\
(\%)\end{array}$ \\
\hline Okur-Yazar Değil & 35,0 & 53,8 & 15,4 & 46,2 & 15,4 & 7,7 & 7,7 & 65,0 \\
\hline Sadece Okur-Yazar & 33,3 & 80,0 & 10,0 & 30,0 & 10,0 & 15,0 & - & 66,7 \\
\hline İlkokul & 32,9 & 52,6 & 31,6 & 26,3 & 17,5 & 15,8 & 10,5 & 67,1 \\
\hline Ortaokul & 32,4 & 66,7 & 22,9 & 39,6 & 6,3 & 12,5 & 10,4 & 67,6 \\
\hline Lise ve Dengi Okullar & 37,9 & 69,4 & 15,7 & 40,7 & 7,4 & 15,7 & 6,5 & 62,1 \\
\hline Üniversite ve Üstü & 38,2 & 65,1 & 25,4 & 26,5 & 7,9 & 19,0 & 6,3 & 61,8 \\
\hline Tümü* & 36,6 & 65,1 & 22,5 & 32,2 & 9,2 & 16,6 & 7,1 & 63,4 \\
\hline
\end{tabular}

Sosyal güvence durumlarına göre sonuçlar incelendiğinde ise, sosyal güvenceye sahip olan ve olmayanların reçetesiz ilaç alma oranlarının yüksek olduğu ve daha çok tercihlerinin daha önce kullanıp faydasını gördüğü ilaca göre oluştuğunu görmekteyiz. Sosyal güvencesi olmayanların reçetesiz ilaç alma tercihlerinde eczacının tavsiyesinin, tanıdık tavsiyesinin ve ilaç fiyatının sosyal güvencesi olanlara göre daha ön planda tutulduğunu görmekteyiz (Tablo 21).

Tablo 21. Katılımcıların eczaneden reçetesiz ilaç alma durumlarında tercihlerinin sosyal güvenceye göre dă̆ılımı

\begin{tabular}{|c|c|c|c|c|c|c|c|c|}
\hline \multirow[b]{3}{*}{ SGK } & \multicolumn{8}{|c|}{ Eczaneden reçetesiz ilaç alıyorsanız bu ilaçları daha çok neye göre tercih edersiniz? En çok iki cevap (\%) } \\
\hline & $\begin{array}{c}\text { Almiyorum } \\
(\%)\end{array}$ & $\begin{array}{l}\text { Daha önce } \\
\text { kullanıp } \\
\text { faydasını } \\
\text { gördüğüm } \\
\text { ilaca göre }\end{array}$ & $\begin{array}{l}\text { Eczacinın } \\
\text { tavsiyesine } \\
\text { göre }\end{array}$ & $\begin{array}{l}\text { Muayenelerde } \\
\text { hekimin } \\
\text { yazdığı ilaçlara } \\
\text { göre } \\
\text { Alıyorum }\end{array}$ & $\begin{array}{l}\text { Tanıdık } \\
\text { tavsiyesine } \\
\text { göre } \\
\text { o) }\end{array}$ & $\begin{array}{l}\text { Danıştığım } \\
\text { hekimin } \\
\text { tavsiyesine } \\
\text { göre }\end{array}$ & $\begin{array}{l}\text { Fiyata } \\
\text { göre }\end{array}$ & $\begin{array}{l}\text { Aliyorum } \\
(\%)\end{array}$ \\
\hline & 37,8 & 67,2 & 22,2 & 31,6 & 9,4 & 16,5 & 6,0 & 62,2 \\
\hline $\begin{array}{l}\text { Özel Sağlık } \\
\text { Sigorta Kurumları }\end{array}$ & 27,1 & 60,0 & 22,9 & 42,9 & - & 20,0 & 11,4 & 72,9 \\
\hline Güvence Yok & 33,8 & 53,1 & 24,5 & 28,6 & 14,3 & 14,3 & 12,2 & 66,2 \\
\hline Tümü* & 36,6 & 65,1 & 22,5 & 32,2 & 9,2 & 16,6 & 7,1 & 63,4 \\
\hline
\end{tabular}

Tüm gelir gruplarında katılımcılar, reçetesiz ilaç alırken daha çok önceden kullanıp faydasını gördüğ̈̈ ilacı tercih ettiklerini belirtmişlerdir. Reçetesiz ilaç alımında ilaç bedeli kullanıcı tarafından tamamı karşılandığından dolayı gelir durumunun, tercihlerdeki etkisine bakıldığında, $1000 \mathrm{TL}$ altı gelire sahip katılımcıların reçetesiz ilaç alımlarında fiyata göre ilaç tercihini $(\% 9,8)$ diğer gelir gruplarından daha çok göz önünde bulundurduğunu görmekteyiz (Tablo 22). 
Nevşehir Bilim ve Teknoloji Dergisi Cilt 6(2) 661-680 2017

Tablo 22. Katılımcıların eczaneden reçetesiz ilaç alma durumlarında tercihlerinin gelir durumuna göre dağılımı Eczaneden reçetesiz ilaç alıyorsanız bu ilaçları daha çok neye göre tercih edersiniz? En çok iki cevap (\%)

\begin{tabular}{|c|c|c|c|c|c|c|c|c|}
\hline & & $\begin{array}{l}\text { Daha önce } \\
\text { kullanıp } \\
\text { faydasını } \\
\text { gördüğüm } \\
\text { ilaca göre }\end{array}$ & $\begin{array}{l}\text { Eczacının } \\
\text { tavsiyesine } \\
\text { göre }\end{array}$ & $\begin{array}{l}\text { Muayenelerde } \\
\text { hekimin } \\
\text { yazdığı } \\
\text { ilaçlara göre }\end{array}$ & $\begin{array}{l}\text { Tanıdık } \\
\text { tavsiyesine } \\
\text { göre }\end{array}$ & $\begin{array}{l}\text { Danıştığım } \\
\text { hekimin } \\
\text { tavsiyesine } \\
\text { göre }\end{array}$ & $\begin{array}{l}\text { Fiyatına } \\
\text { göre }\end{array}$ & \multirow[b]{2}{*}{$\begin{array}{c}\text { Aliyorum } \\
(\%)\end{array}$} \\
\hline & $\begin{array}{c}\text { Almiyorum } \\
(\%)\end{array}$ & \multicolumn{6}{|c|}{ Aliyorum (\%) } & \\
\hline 1000 TL'nin Altı & 36,1 & 60,7 & 21,5 & 33,1 & 8,0 & 12,9 & 9,8 & 63,9 \\
\hline 1000-1335 TL Aras 1 & 36,6 & 62,2 & 26,1 & 34,2 & 9,9 & 16,2 & 6,3 & 63,4 \\
\hline 1336-2000 TL Aras1 & 37,5 & 74,1 & 23,5 & 34,1 & 10,6 & 22,4 & 2,4 & 62,5 \\
\hline 2000 TL Üzeri & 36,7 & 68,4 & 18,4 & 25,0 & 9,2 & 18,4 & 7,9 & 63,3 \\
\hline Tümü* & 36,6 & 65,1 & 22,5 & 32,2 & 9,2 & 16,6 & 7,1 & 63,4 \\
\hline
\end{tabular}

Sağlık ocağında ilaç yazdıranların hekimin kararının dışında tercihlerini hangi kriterlere göre belirlediklerini öğrenmeyi amaçladığımız anket sorumuzun cevapları incelendiğinde, sağlık ocağında ilaç yazdırmayanların sayısı 119 (\%17,3), yazdıranların sayısı 567 (\%82,7)'dir. İlaç yazdıran 567 kişiye en çok iki cevap hakkı sunulmuş olup 843 cevap verilmiştir. Bu cevaplar incelendiğinde, sağlık ocağında ilaç yazdıran katılımcıların \% 77,8'i genellikle muayene sonucu hekimin yazdığı ilacı kabul ederek, \% 27,2’sinin ise daha önce faydasını gördüğü ilaca göre belirlediğini görmekteyiz (Tablo 23).

Tablo 23. Sağlık ocağında ilaç yazdıran katılımcıların tercihlerini neye göre belirlediğinin il ve genel bazda dağılımı Sağlık ocağında ilaç yazdırıyorsanız, bu ilaçları genellikle neye göre belirlersiniz? En çok iki cevap (\%)

\begin{tabular}{|c|c|c|c|c|c|c|c|c|}
\hline \multirow[b]{3}{*}{ Nevşehir } & \multirow{3}{*}{$\begin{array}{c}\text { Yazdirmiyorum } \\
\begin{array}{c}(\%) \\
37,3\end{array}\end{array}$} & $\begin{array}{l}\text { Muayene sonucu } \\
\text { hekimin yazdığ } 1 \\
\text { ilacı kabul } \\
\text { ederim }\end{array}$ & $\begin{array}{c}\text { Eczacinın } \\
\text { tavsiyesine } \\
\text { göre }\end{array}$ & $\begin{array}{l}\text { Tanıdık } \\
\text { tavsiyesine } \\
\text { göre }\end{array}$ & $\begin{array}{l}\text { Daha önce } \\
\text { faydasını } \\
\text { gördüğüm } \\
\text { ilaca göre }\end{array}$ & $\begin{array}{l}\text { Danıştığım } \\
\text { hekimin } \\
\text { tavsiyesine } \\
\text { göre }\end{array}$ & $\begin{array}{c}\text { Her an } \\
\text { ihtiyacım } \\
\text { olabilecek } \\
\text { ilaçlara } \\
\text { göre }\end{array}$ & \multirow{3}{*}{$\begin{array}{c}\text { Yazdırıyorum } \\
(\%) \\
62,7\end{array}$} \\
\hline & & \multicolumn{6}{|c|}{ Yazdırıyorum (\%) } & \\
\hline & & 65,6 & 12,5 & 12,5 & 40,6 & 15,6 & 3,1 & \\
\hline Kayseri & 13,4 & 80,1 & 13,6 & 4,4 & 23,4 & 20,3 & 7,0 & 86,6 \\
\hline Niğde & 14,6 & 74,3 & 12,9 & 12,9 & 25,7 & 17,1 & 12,9 & 85,4 \\
\hline Aksaray & 20,7 & 78,4 & 10,2 & 3,4 & 25,0 & 15,9 & 2,3 & 79,3 \\
\hline Kurşehir & 20,8 & 75,4 & 3,3 & 3,3 & 44,3 & 13,1 & 19,7 & 79,2 \\
\hline Tümü* & 17,3 & 77,8 & 11,8 & 5,6 & 27,2 & 18,2 & 8,1 & 82,7 \\
\hline
\end{tabular}

Yaş dağılımına göre sonuçlarımızı incelediğimizde, yaş arttıkça hekimin muayene sonucu yazdığı ilacı kabul etme oranının arttı̆̆ını, her an ihtiyaç olunabilecek ilaçlara göre tercih eğiliminin ise azaldığını söyleyebiliriz (Tabloda gösterilmemiştir).

İlaç kullanımı alışkanlıklarından prospektüs veya kullanma talimatı bilgilerinin okunup okunmadığını, okunuyorsa hangi bölümlerine daha çok ağırlık verildiğini anlamayı amaçladığımız anket sorumuzda, katılımcıların 149 (\% 21,7)'u kullandıkları ilacın prospektüs veya kullanma talimat bilgilerini hiç okumazken, 537 (\% 78,3)'si okuduğunu belirtmişlerdir.

Okuyan 537 kişinin, okuduğu kısımları seçmesi istenmiş ve toplamda 2240 seçim işlemi yapılmıştır. Yapılan seçimlerin yüzdesi azalan şekilde incelendiğinde; okuyan katılımcıların \% 71,1' $\mathrm{i}$ ilacın neye yaradığını (endikasyonu), \% 68,7'sinin yan etkiler kısmını, \% 56,6'sının ilacın kullanım şeklini, \% 44,7'sinin uyarılar kısmını, \% 43'nün kullanılmaması gereken durumları (kontraendikasyonu), 
\% 36,9'nun dozlar kısmını, \% 36,3'nün kullanım süresini, \% 31,1'nin saklama koşullarını ve \% 28,7’sinin diğer ilaçlarla olan etkileşimler kısmını okuduğunu görmekteyiz (Tablo 24).

Tablo 24. Prospektüs veya kullanma talimatını okuyan katılımcıların hangi kısımlarını okuduğunun il ve genel bazda dağılımı

\begin{tabular}{|c|c|c|c|c|c|c|c|c|c|c|c|}
\hline \multirow[b]{3}{*}{ Nevşehir } & \multicolumn{11}{|c|}{ Aldığınız ilacın prospektüs veya kullanma talimat bilgilerinin hangi kısımlarını okursunuz? Çoklu cevap (\%) } \\
\hline & \multirow{2}{*}{$\begin{array}{c}\text { Okumam } \\
\qquad \%) \\
33,3\end{array}$} & \multirow{2}{*}{$\begin{array}{c}\begin{array}{c}\text { İlacın } \\
\text { neye } \\
\text { yaradığ } 1\end{array} \\
91,2\end{array}$} & \multirow{2}{*}{$\begin{array}{c}\begin{array}{c}\text { Kullanım } \\
\text { şekli }\end{array} \\
47,1\end{array}$} & \multirow{2}{*}{$\begin{array}{c}\begin{array}{c}\text { Yan } \\
\text { etkiler }\end{array} \\
76,5\end{array}$} & \multirow{2}{*}{$\begin{array}{c}\begin{array}{c}\text { Diğer } \\
\text { ilaçlarla } \\
\text { olan } \\
\text { etkileşimi } \\
\text { OP }\end{array} \\
26,5\end{array}$} & \multirow{2}{*}{$\begin{array}{l}\text { Doz } \\
\frac{\text { arum }(9}{26,5}\end{array}$} & \multirow{2}{*}{$\begin{array}{l}\text { Uyar1 } \\
\text { 6) } \\
38,2\end{array}$} & \multirow{2}{*}{$\begin{array}{c}\begin{array}{c}\text { Kullanıl- } \\
\text { mamas1 } \\
\text { gereken } \\
\text { durumlar }\end{array} \\
41,2\end{array}$} & \multirow{2}{*}{$\begin{array}{c}\begin{array}{c}\text { Kullanım } \\
\text { süresi }\end{array} \\
29,4\end{array}$} & \multirow{2}{*}{$\begin{array}{c}\text { Saklama } \\
\text { koşulları }\end{array}$} & \multirow{2}{*}{$\begin{array}{c}\text { Okurum } \\
(\%) \\
66,7\end{array}$} \\
\hline & & & & & & & & & & & \\
\hline Kayseri & 23,8 & 65,5 & 56,8 & 70,5 & 22,7 & 33,8 & 42,8 & 34,9 & 32,4 & 28,1 & 76,2 \\
\hline Niğde & 18,3 & 74,6 & 37,3 & 49,3 & 28,4 & 31,3 & 43,3 & 47,8 & 31,3 & 23,9 & 81,7 \\
\hline Aksaray & 17,1 & 68,5 & 59,8 & 62,0 & 31,5 & 39,1 & 42,4 & 48,9 & 38,0 & 32,6 & 82,9 \\
\hline Kırşehir & 14,3 & 84,8 & 75,8 & 86,4 & 51,5 & 57,6 & 60,6 & 65,2 & 59,1 & 54,5 & 85,7 \\
\hline Tümü* & 21,7 & 71,1 & 56,6 & 68,7 & 28,7 & 36,9 & 44,7 & 43,0 & 36,3 & 31,1 & 78,3 \\
\hline
\end{tabular}

Katılımcıların eğitim durumlarının, ilacın prospektüs veya kullanma talimatının hangi kısımlarını okuduğuna etkisi incelendiğinde, eğitim düzeyinin artışıyla prospektüs veya kullanma talimatının genel anlamda okunma oranının arttığını, bununla beraber okunan kısımlarına bakıldığında ise ilacın neye yaradığı, yan etkileri, diğer ilaçlarla olan etkileşimleri, dozu, kullanılmaması gereken durumlar ve kullanım süresi bölümlerinin üniversite ve üzeri eğitim seviyesine sahip katılımcılar tarafından daha çok okunduğunu söyleyebiliriz (Tablo 25).

Tablo 25. İlacın prospektüs veya kullanma talimatı bilgilerini okuyan katılımcıların hangi kısımlarını okuduğunun eğitim düzeylerine göre dağılımı

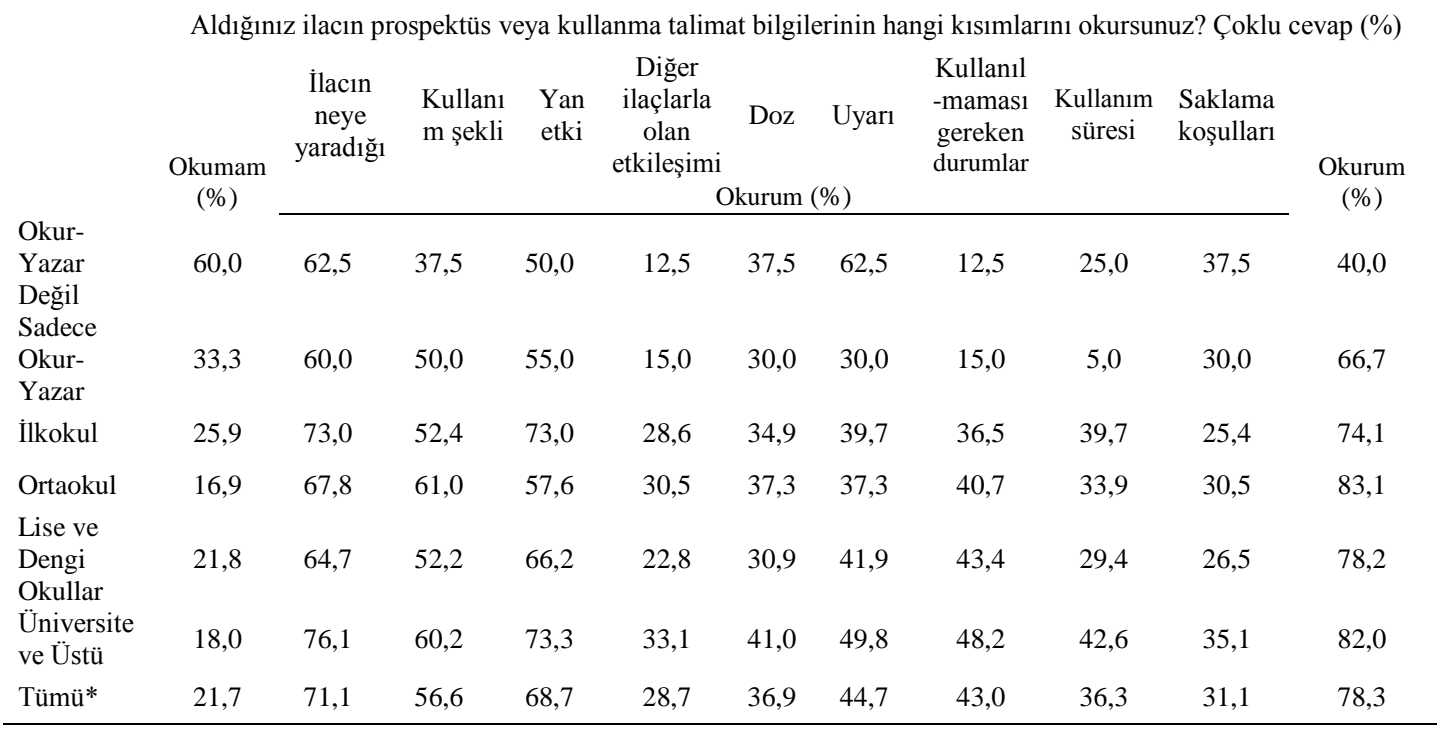

Çalışmamızın diğer bir bölümünde katılımcılara yöneltilen ifadelere verdikleri cevaplar değerlendirilmiştir. İlaç kullanım alışkanlığını incelemeye yönelik olan ifadelerin tümüne cevap vermeleri istenmiş olup, cevapların yüzde (\%) olarak dağılımı Tablo 26'de gösterilmiştir. 
Tablo 26. İlaç kullanım alıșkanlıklarını incelemeye yönelik katılımcılara yöneltilen ifadelere verilen cevapların dağılımı

\begin{tabular}{lcc}
\hline & Evet (\%) & Hayır (\%) \\
İlaçların son kullanma tarihlerini takip ederim & 80,0 & 20,0 \\
Hekime ilaçlarımın nasıl kullanılacağını sorarım & 16,9 \\
Muadil ilaç kullanmaktan rahatsızlık duyarım & 83,1 & 43,4 \\
Sağlık çalışanı olmayan birinin tavsiyesiyle ilaç kullanırım & 56,6 & 74,9 \\
Hasta olduğum zamanlarda hekime başvurmadan önce ilaç kullandığım olur & 25,1 & 38,3 \\
Tanıdık/arkadaş ve aileme ilaç tavsiye ettiğim olur & 61,7 & 65,0 \\
İlacı hekimin veya eczacının anlattığı şekillerde kullanmadığım olur & 35,0 \\
İlaç almayı unuttuğum zamanlar olur & 44,9 & 55,1 \\
Muayene olmadan sağlık kuruluşlarında ilaç yazdırırım & 68,5 & 31,5 \\
Lüzum olur diye sağlık ocağına ilaç yazdırmaya giderim & 38,6 & 61,4 \\
Eczacım bana reçetesiz ilaç veya takviyeler önerir. & 33,4 & 66,6 \\
Herhangi bir şikayet ya da hastalığım için kendi kendime ilaç kullanırım & 27,6 & 72,4 \\
Birde fazla ilaç kullanmam gerektiğinde hangisinin ne için olduğunu karıştırdığım olur & 38,2 & 61,8 \\
Hastalanacağımı hissettiğim anlarda evde olan ilaçlardan kullanırım & 64,6 & 35,4 \\
Kronik bir hastalığınız (sürekli ilaç kullanımınızı gerektiren) var mı? & 25,1 & 74,9 \\
Evde bulunan ilaç atıklarınızı imha etmek için muhatap bulabiliyor musunuz? & 31,5 & 68,5 \\
\hline
\end{tabular}

Kapadokya bölgesi bazında, doktora veya eczacıya danışmadan reçetesiz ilaç alan katılımcıların \% 54,1'inin en çok ağrı kesici ilacı aldığını, bunu takiben \% 19,2'si antibiyotik, \% 7,4'ü tansiyon düşürücü, \% 7,2'si soğuk algınlı̆̆ı, \% 3,6'sı kas gevşetici, \% 2,3'ü vitamin, \% 2,1'i ateş düşürücü, \% 1,7'si depresyon ilacı, \% 1,3'ü öksürük şurubu ve \% 1,1'i ise burun spreyi ilacını aldığını görmekteyiz. İl bazında bakıldığında ise doktora veya eczacıya danışmadan en çok reçetesiz alınan ilacın tüm il merkezlerinde ağrı kesici ilaç olduğunu görüyoruz (Tablo 27).

Tablo 27. Doktora veya eczacıya danışmadan reçetesiz alıp kullanılan ilaçların sıklığına göre tercih dağılımı

Doktora veya eczacıya danışmadan en çok reçetesiz alıp kullanılan ilaçların il ve genel bazda dağılımı. Tek cevap (\%)

\begin{tabular}{ccccccccccc} 
& Antibiyotik & $\begin{array}{c}\text { Ağrı } \\
\text { Kesici }\end{array}$ & $\begin{array}{c}\text { Tansiyon } \\
\text { Düşürücü }\end{array}$ & $\begin{array}{c}\text { Kas } \\
\text { Gevşetici }\end{array}$ & $\begin{array}{c}\text { Depresyon } \\
\text { İlac1 }\end{array}$ & $\begin{array}{c}\text { Ateş } \\
\text { Düşürücü }\end{array}$ & $\begin{array}{c}\text { Öksürük } \\
\text { Şurubu }\end{array}$ & $\begin{array}{c}\text { Burun } \\
\text { Spreyi }\end{array}$ & $\begin{array}{c}\text { Soğuk } \\
\text { Algınlığı } \\
\text { İlacı }\end{array}$ & Vitamin \\
Nevşehir & 22,0 & 56,1 & 4,9 & 4,9 & 2,4 & - & - & - & 4,9 & 4,9 \\
Kayseri & 20,5 & 48,5 & 8,5 & 5,1 & 2,0 & 2,7 & 1,4 & 1,0 & 8,2 & 2,0 \\
Niğde & 15,2 & 59,1 & 9,1 & - & 1,5 & 1,5 & - & - & 12,1 & 1,5 \\
Aksaray & 10,5 & 68,4 & 6,6 & - & 1,3 & 1,3 & 2,6 & 3,9 & 2,6 & 2,6 \\
Kırşehir & 27,5 & 56,9 & 2,0 & 3,9 & - & 2,0 & 2,0 & - & 3,9 & 2,0 \\
Tümü* & 19,2 & 54,1 & 7,4 & 3,6 & 1,7 & 2,1 & 1,3 & 1,1 & 7,2 & 2,3 \\
\hline
\end{tabular}

\section{Tartışma ve Sonuç}

Çalışmamız, Kapadokya Bölgesinde; Nevşehir, Kayseri, Niğde, Aksaray ve Kırşehir'de bulunan il merkezlerindeki insanların ilaç kullanım alışkanlıklarını ve farkındalıklarını saptamaya yönelik yapılmış ilk çalışma olması vasıtasıyla daha sonra yapılacak çalışmalara veri sağlamak amacıyla yapılmıştır. Bölgede bulunan il merkezlerinde 18 yaş üzeri 686 kişiye yüz yüze anket yöntemi ile ulaştık.

Bölgedeki katılımcıların cinsiyetlerine göre dağılımları incelendiğinde, \% 50,4'ü kadın, \%49,6's1 erkek olarak dağılım göstermiştir. Anket yapılan kişilerin yaş dağılımlarına bakıldığında katılımcıların çoğunluğunu 294 kişi olarak (\%42,9) 18-24 yaş arası grup olup, 246’sını $(\% 35,9)$ 25-44 yaş arası, 
120 'sini $(\% 17,5)$ 45-64 yaş arası ve 26'sını $(\% 3,8) 65$ yaş ve üstü grup oluşturmuştur. Akılcı ilaç kullanımı alışkanlığında rolü olabilecek olan eğitim düzeyleri, araştırmamızda analizlerin yorumlanmasında kullanılan önemli kriterlerden biridir. Araştırmamıza katılan kişilerin büyük bir çoğunluğunu 306 kişiyi $(\% 44,6)$ üniversite ve/veya üzeri katılımc1lar oluşturmuştur. Sosyal güvence durumu incelendiğinde, katılımcıların 564'ü (\%82,2) SGK'l1, 48’i (\%7) özel sağlık sigortalı, 74’ü $(\% 10,8)$ ise sağlık güvencesi olmayan kişilerden oluşmaktadır.

Doktora veya eczacıya danışmadan reçetesiz ilaç alanların sayısı 527 ( \%76,8), almayanların sayısı ise 159 (\%23,2)'dir. Isparta'da yapılan çalışmada \% 42,9'u doktora danışmadan kullandıklarını söylemişlerdir [8]. Özçelikay ve arkadaşlarının yaptığı bir çalışmada kişilerin \% 90,2'si doktora gitmeden ilaç kullandığını söylemiştir [10]. Iptes ve Khorshid'in araştırmasında öğrencilerin \% 44,2'sinin reçetesiz olarak ilaç kullandıkları saptanmıştır [11]. Özkan ve arkadaşlarının yaptığı çalışmada hastaların \% 31,9’u hasta olduklarında doktora gitmeden eczaneden ilaç almışlardır [12]. İlaç alan katılımcıların \% 54,1'i en çok ağıı kesici ilacı aldığını, bunu takiben \% 19,2'si antibiyotik ilacını aldığını görmekteyiz. Pınar'ın yaptığı çalışmada doktora danışmadan ilaç kullanan kişilerin \% 98,4'ü ağrı kesici ateş düşürücü ilaç, \% 53,1'i anti gribal ilaç, \% 34,3'ü antibiyotik kullandıklarını söylemişlerdir [13]. Muğla'da yapılan çalışmada doktora danışmadan kullanılan ilaçlar, \% 92,4 ile ağrı kesiciler, \% 16,3 ile antibiyotikler bulunmuş̧tur [14]. Ankara'da yapılan bir çalışmada araştırmaya katılanların \% 93,7'si ağrı kesici ilaçları doktora danışmadan kullandığını söylemiştir [15]. Ankara üniversitesi öğrencilerinde yapılan çalışmada doktora başvurmadan kullanılan ilaçların \% 63'ü ağnı kesiciler, \% 12,5'i anti gribal ilaçlar, \% 4,5' $\mathrm{i}$ antibiyotikler bulunmuştur [16]. Tüm dünyada analjezik ilaçlar en sık kullanılan ilaçlar arasındadır. Çalışmamızda analjeziklerden sonra en sık uygunsuz kullanılan ilaç anti gribal ilaçlar ve antibiyotikler bulunmuştur.

Çalışmamızda, katılımcıların \% 25,1'nin sağlık çalışanı olmayan birinden tavsiyesi ile ilaç kullandığını bildirmişlerdir. Özkan ve arkadaşlarının çalışmasında görüşülen kişilerin \% 25,6'sı tavsiye ile ilaç kullandıklarını söylemişlerdir [12]. Ankara ili merkez sağlık ocaklarında yapılan araştırmaya katılanların \% 39,4'ü tavsiye ile ilaç kullandığını, \% 12,3’ü de ilaç tavsiye ettiklerini belirtmişlerdir [17].

Katılımcıların rahatsızlandıklarında ilk olarak ne yaptıklarını saptamaya yönelik sorduğumuz soruda, katılımcıların \% 64'ü ilk olarak muayene olmaya sağlık kuruluşuna gitmeyi, \% 14,6'sının evdeki ilaçlarla tedavisini yapmayı, \% 8'nin rahatsızlığının geçmesini beklediğini yaptıkları saptanmıştır. İlhan ve arkadaşları katılımcıların \%59,5'i sağlık sorunu olduğunda ilk olarak sağlık kuruluşuna başvurduğunu belirtirken, \% 30,2'si evdeki mevcut ilaçları kullandığını, \% 20,8'i ise bitkisel / geleneksel yöntemlere başvurduğunu ifade etmiştir [9]. Ankara'da 2008 yılında yapılan bir araştırmada katılımcıların \% 60,5' $\mathrm{i}$ bir sağlık problemiyle karşılaştıklarında ilk olarak doktora başvurduğunu belirtmiştir [18]. Türkiye genelinde 2011 yılında yapılan "Toplumda Antibiyotik Kullanımı Sıklı̆ıı ve Hekimlerin Antibiyotik Reçetesi Yazma Durumları İle İlişkili Etmenlerin Belirlenmesi” adlı araştırmada; incelenenlerin \% 65,4’ü sağlık sorunu olduğunda ilk olarak doktora başvurduğunu, \% 17,1'i evdeki ilaçları kullandığını \% 14,9'u bitkisel-geleneksel yöntem kullandığını belirtmiştir [19].

Çalışmamızda katılımcıların \% 92,9'u ilaç hakkında bilgi almak için bir başvuruda bulunurken, \% 7,1'i bilgi almak için başvuru yapmamaktadır. İlaç hakkında bilgi almak için başvuru yapan katılımcıların ilk olarak \% 49'nun hekime başvurarak bilgi edindiği sonucuna ulaşıllmıştır. Pınar'ın 
çalışmasında, ankete katılan kişilerin \% 32,5'i doktordan, verdiği ilaç hakkında bilgi istediğini söylemişlerdir [13]. Özkan ve arkadaşlarının çalışmasında görüşülen kişilerin \% 54'ü doktorundan ilaçlar hakkında bilgi almak istediklerini belirtmişlerdir [12]. Çalışmamızda ilaç hakkında bilgi almak için ilk olarak hekime başvurunun eğitim seviyesiyle arttığı ve akılcı olmayan bilgi edinme tercihlerinin de azaldığını söyleyebiliriz.

Prospektüs veya kullanma talimatı bilgilerinin okunup okunmadığını, okunuyorsa hangi bölümlerine daha çok ağıllık verildiğini incelediğimizde, Anketi gerçekleştirenlerin ilacın prospektüs veya kullanma talimat bilgilerini 149 (\% 21,7)'u hiç okumazken, 537 (\% 78,3) kişi okumuştur. Okuyan katılımcıların \% 71,1'i ilacın neye yaradığını (endikasyonu), \% 68,7'sinin yan etkiler kısmını, \% 56,6'sının ilacın kullanım şeklini okuduğunu görmekteyiz. Adana'da yapılan ilaç kullanım alışkanlığı araştırmasında, katılımcıların \% 72,1'i kullandıkları ilacın prospektüslerini okuduklarını söylemişlerdir [13]. Muğla'da yapılan çalışmada katılımcıların \% 96,6'sı prospektüsü okuduklarını söylemişlerdir [14]. Iptes ve arkadaşlarının çalışmasında öğrencilerin \% 80,8’i ilaç kullanmadan önce prospektüsü okuduklarını söylemişlerdir [11]. Çalışmamızla uyumlu bulunmuştur. Çalışmamızda eğitim düzeyinin artı̧̧ıla prospektüs veya kullanma talimatının genel anlamda okunma oranının arttığı söyleyebiliriz. Pınar, eğitim düzeyi arttıkça kullanılan ilacın prospektüsünü okuma durumunun da arttı̆̆ını saptamıştır [13]. Özkan ve arkadaşlarının çalışmasında da çalışmamıza benzer olarak eğitim düzeyi ile ilacın prospektüsünü okumanın arttığı gözlenmiştir [12].

İlacı kullanırken istenmeyen bir etki ile karşılaştı̆ıında, katılımcıların ilk olarak \% 65'nin hekime, \%10,6'sının eczacıya, \% 9,6'sının ilacın prospektüs veya kullanma talimatına başvurduğunu görmekteyiz. Adana ilindeki çalışmada, katılımcıların \% 40,6'sı ilacında yan etki gördüğünde doktora başvurduğunu söylemiştir [13]. Muğla'daki çalışmada katılımcıların \% 36,5'i yan etki gördüğünde ilacı bıraktıklarını belirtmişlerdir [14]. Manisa'daki çalışmada ise kişilerin \% 54,2'si yan etki gördüğünde doktora başvurduklarını söylemiş̧lerdir [20]. Ankara'da Batıkent 2 no'lu sağlık ocağı bölgesinde yapılan çalışmada katılımcıların \% 43,7'si ilacın yan etkisi olduğunda doktora başvurduklarını söylemişlerdir [21]. İlaçta yan etki görüldüğünde doktora veya eczacıya başvurmak akılcı ve en doğru olan yaklaşımdır.

Çalışmamızda, Katılımcıların \% 80'nı ilaçların son kullanma tarihlerini takip ettiklerini söylemişlerdir. Pınar'ın çalışmasında, ilacı kullanmadan önce son kullanma tarihine bakanların oranı \% 85,8 bulunmuştur [13]. Ankara'da yapılan çalışmada katılımcıların \% 88,4'ü ilaçların son kullanma tarihlerine baktıklarını söylemişlerdir [22].

Kapadokya bölgesi illeri merkezinde yaşayan 18 yaş üzeri katılımcıların \% 37,9’u genellikle ilaçlarını buzdolabında, bunu takiben \% 25,8'i çekmece/dolapta, \% 23,8'i ecza dolabında, \%11,2'si 1sı koşullarına göre saklama yerlerini mevsime göre değiştirdiği görülmektedir. Pınar, çalışmasında katılımcıların \% 45,1'inin ilaçları buzdolabında sakladıkları sonucuna ulaşmıştır [13]. Ankara'daki çalı̧̧mada katılımcıların \% 42,2'si ilaçlarını buzdolabında sakladıklarını, \% 23,2'si ise ecza dolabında ve oda sıcaklığında sakladıklarını ifade etmişlerdir [22]. İlaç Endüstrisi İşverenler Sendikası'nın 26 ilde yaptığı bir çalışmada katılımcıların \% 64,5'i ilaçlarını buzdolabında sakladıklarını söylemiş̧lerdir [23]. Batıkent sağlık ocağında yapılan çalışmada bireylerin \% 43,5'i ilaçlarını buzdolabında sakladıklarını belirtmişlerdir [21]. İlaç türüne göre saklanma koşulları değişebilmekle birlikte genel olarak ilaçların 
üzerinde yazan dereceye göre saklanması veya 1sı koşullarına göre saklanması daha uygun olacağı söylenebilir.

Çalışmamızda, katılımcıların \% 51,5'i lazım olur diye ilaç aldığından evde kullanılmayan ilaçların bulunduğunu söylemişlerdir. Adana'da yapılan bir çalışmaya katılanların \% 28,9'u evde bulunsun diye ilaç yazdırdıklarını söylemişlerdir [13]. Ankara'daki çalışmada kişilerin \% 43,6'sı ilaç yazdırmaya gittiklerini söylemişlerdir, ilaç yazdırmaya gidenlerin evlerinde artık ilaç bulunma yüzdesi yüksek çıkmıştır [22].

Çalışmamızda Kapadokya bölgesinde bulunan il merkezlerinde yaşayanlara evlerinde son kullanma tarihi geçmiş veya bozulmuş ilaçları fark ettiklerinde genellikle ne yaptıklarını sorduğumuzda, bölge genelinde katılımcıların \% 65,3'ü çöpe attıklarını, \%11,8'i evde sakladığını, \% 8'i lavaboya veya tuvalete döktüklerini söylemişlerdir. Pınar, tez çalışmasında; katılımcıların \% 49'unun son kullanma tarihi geçen ilaçları çöpe attıklarını, \% 13,7'sini hastane, eczane, sağlık ocağına verdiğini söylemiştir [13]. Muğla'da yapılan çalışmada son kullanma tarihi geçen ilaçları, kişilerin \% 56,8'i evde sakladığını, \% 24'ü attığını, \% 9,6'sı sağlık kuruluşuna verdiğini söylemiştir [14].

Araştırmamızda katılımcıların \% 64,6'sı hastalanacağını hissettiği anlarda evdeki ilaçlardan kullandığını söylemişlerdir. Ankara'da sağlık ocaklarına başvuran hastalarda yapılan bir araştırmada hastaların \%65,5'inin hastalandıkları zaman ilk olarak evde bulunan ilaçları kullandıkları belirlenmiştir [24]. Antalya'da yapılan bir çalışmada ise bu oran \%43,5 olarak belirtilmiştir [25].

Toplumun hasta olduklarındaki tutumları; sağlığı algılamaları, sağlk bilgi düzeyleri, eğitim durumları, gelir düzeyleri, sağlık kurumlarından beklentileri gibi birçok faktörden etkilenmektedir. Bu nedenle değişik bölgelerde farklı sonuçlar çıkmaktadır. Kişilerin ilaç kullanım tutum ve davranışlarının belirlenmesinde; ilaç yazma yetkisine sahip olan hekimlerin ilaç bilgisi, hastaya yaklaşımı, bilgilendirilmesi kadar, hastaların sosyodemografik özellikleri ve sosyal çevrelerinden etkilenmeleri de rol oynamaktadır [26], [27].

Katılımcılarımızın büyük bölümünün ilaç kullanım alışkanlıkları, akılcı ilaç kullanım ilkelerine uymadığını söyleyebiliriz. Akılcı ilaç kullanım ilkeleriyle örtüşmeyen bu gibi yaklaşımların önüne geçilebilmesi için toplumu oluşturan bireylere akılcı ilaç kullanımına yönelik eğitimlerin yapılması gerekmektedir. Gelecekte planlanması düşünülen eğitim müfredatlarına 1şık tutması ve akılcı ilaç kullanımının yaygınlaştııılması açısından, genel olarak toplumda ve bazı özel gruplarda (gebeler, yaşlılar, vb.) ilaç kullanma alışkanlıkları ve akılcı ilaç kullanımı ile ilgili durum tespitinde bulunan detaylı çalışmaların yapılması ilaç kullanımında yaşanan sorunların aşılmasına yüksek oranda katkı sağlayacaktır.

\section{Teșekkür}

$\mathrm{Bu}$ çalışma, Nevşehir Hacı Bektaş Veli Üniversitesi Bilimsel Araştırma Projeleri Koordinatörlüğü (NEHÜBAP) tarafindan NEÜÖBAP 15/2 F1 proje numarası ile desteklenmiştir. Akılc1 ilaç kullanımı dersi kapsamında, projenin anket çalışmasında emeği geçen Nevşehir Hacı Bektaş Veli Üniversitesi Sağlık Hizmetleri Meslek Yüksekokulu öğrencilerine katkılarından dolayı teşekkürlerimizi sunarı. 


\section{Kaynaklar}

[1] Akkurt B., “Araştırma görevlilerinin (branş) akılcı ilaç kullanımı konusunda bilgi tutum ve davranışları”, Yıldırım Beyazıt Üniversitesi, Tıp Fakültesi, Uzmanlık Tezi, Ankara, 2016

[2] (2016, 2 Temmuz), "Neden akılcı ilaç kullanımı", Türkiye İlaç ve Tıbbi Cihaz Kurumu sitesinden alınmıştır. http://www.akilciilac.gov.tr/?page_id=81

[3] Patel V., Vaidya R., Naik D., Borker P., "Irrational drug use in India: A prescription survey from Goa” J Postgrad Med, 51, 9-12, 2005

[4] Acar A., Yeğenoğlu S., "Akılcı ilaç kullanımı penceresinden farmakoekonomi ve hastane formülerleri” Ankara Eczacılık Fakültesi Dergisi, 34 (3), 207 -218, 2005

[5] (2016, 20 Temmuz), “Akılcı İlaç Kullanımı Eylem Planı” Akılcı İlaç Kullanımı sitesinden alınmıştır. http://www.akilciilac.gov.tr/wp-content/uploads/2014/11/aik-ulusal-eylem-plani.pdf

[6] Şahingöz M., "Hemşirelerin akılcı ilaç kullanımı ve uygulaması konusunda bilgi, tutum ve davranışlarının değerlendirilmesi”, Erciyes Üniversitesi, Sağlık Bilimleri Enstitüsü, Yüksek Lisans Tezi, Kayseri, 2012

[7] Chapra C., S., Canale R., P., "Topluma yönelik akılcı ilaç kullanımı” Sosyal Güvenlik Kurumu (Marmara Üniversitesi tarafından yürütülen "Sosyal Güvenlik Kurumu'nun Akılcı İlaç Kullanımı Etkinliklerine Yönelik Alt Yapı Oluşturma ve Geliştirme Projesi Kapsamında), 54s, Ankara, 2013

[8] Uskun E., Uskun S.B., Öztürk M., Kişioğlu A.N, "Sağlık ocağına başvuru öncesi ilaç kullanımı" Sürekli Tıp Ĕ̆itimi Dergisi, 13(12), 451-454, 2004

[9] İlhan MN., Aydemir Ö., Çakır M., Aycan S., “Akılcı olmayan ilaç kullanım davranışları: Ankara’da üç ilçe örneği” Turkısh Journal of Publıc Health, 12(3), 188-200, 2014

[10] Özçelikay G., “Akılcı ilaç kullanımı üzerinde bir pilot çalışma” Ankara Eczacılık Fakültesi Dergisi, 30(2), 9-18, 2001

[11] Iptes S., Khorshıd L., "Üniversite öğrencilerinin ilaç kullanım durumlarının incelenmesi” Ege Üniversitesi Hemşirelik Yüksek Okulu Dergisi, 20(1), 97-106, 2004

[12] Özkan S., Özbay OD., Aksakal FN., İlhan MN., Aycan S., "Bir üniversite hastanesine başvuran hastaların hasta olduklarındaki tutumları ve ilaç kullanım alışkanlıkları" TSK Koruyucu Hekimlik Bülteni, 4(5), 223-37, 2005

[13] Pınar N., “Adana ilindeki insanların ilaç kullanım alışkanlıkları”, Çukurova Üniversitesi, Tıp Fakültesi, Uzmanlık Tezi, Adana, 2010

[14] Baybek H., Bulut D., Çakır A., "Muğla Üniversitesi idari personelinin ilaç kullanma alışkanlıklarının belirlenmesi” Muğla Üniversitesi Sosyal Bilimler Enstitüsü Dergisi, 15, 53-67, 2005

[15] Önder E., Koçıa O., Öztürk S., Sabuncu Z., Soyutemiz Ö., Altıntaş A., "Yunus Emre sağlık ocağı bölgesinde yaşayan 18 yaş ve üstü bireylerin ağrı kesici kullanımı ve bu konudaki bazı bilgilerin saptanması" Toplum Hekimliği Bülteni, 21(1), 2002

[16] Özçelikay G., Asil E., Köse K., “Ankara üniversitesi öğrencilerinin doktora gitme ve doktora başvurmadan ilaç kullanma alışkanlıkları üzerinde bir çalışma” Ankara Eczacılık Fakültesi Dergisi, 24(1), 21-31, 1995 
[17] Mollahaliloğlu S., Tezcan S., "Ankara il merkezinde bulunan sağlık ocaklarında çalışan hekimlerin akılcı ilaç kullanımı açısından değerlendirilmesi” 8.ulusal halk să̆lı̆̆ı kongresi 2328 Eylül, Bildiri kitabı, 499-501 s, Diyarbakır, 2002

[18] İlhan MN., Durukan E., İlhan SO., Aksakal FN., Özkan S., Bumin MA., "Self-medication with antibiotics: questionnaire survey among primary care center attendants" Pharmacoepidemiology and Drug Safety, 18(12), 1150-1157, 2009

[19] İlhan M., "Toplumda antibiyotik kullanımı sıklığg ve hekimlerin antibiyotik reçetesi yazma durumları ile ilişkili etmenlerin belirlenmesi araştırması” T.C. Sağlık Bakanlığı Refik Saydam Hıfzıssıhha Merkezi Başkanlığı, Ankara, 2011

[20] Yılmaz E.,Yılmaz E., Karaca F., Uçar S., Yüce T., "Sağl1k yüksekokulu öğrencilerinin ilaç kullanma durumlarının incelenmesi” Ftrat Sağlık Hizmetleri Dergisi, 3(8), 69-83, 2008

[21] Altıntaş H., Beyhun NE., Tezcan ME., Çelebi S., Ünal M., Turan O., Yücel O., "Batıkent-2 nolu sağlık ocağı bölgesindeki basın-iş 19 sitesinde yaşayan 15 yaş ve üstü bireylerin akılcı ilaç kullanımlarının saptanması” 8. Halk Sağlı̆̆ı Günleri 23-25 Haziran, Bildiri özetleri, 63 s, Sivas, 2003

[22] Göçgeldi E., Uçar M., Açıkel CH., Türker T., Hasde M., Ataç A., "Evlerde atık ilaç bulunma sıklığı ve ilişkili faktörlerin araştırılması" TAF Preventive Medicine Bulletin, 8(2), 113-118, 2009

[23] (2015, 15 Temmuz) “Ülkemizin İlaç Kullanım Davranışları belirlendi”, İlaç Endüstrisi İşverenler Sendikası (İEIS). http://www.ieis.org.tr/ieis/tr/press/14/ulkemizin-ilac-kullanimdavranislari-belirlendi

[24] Rasyonel İlaç Bölümü, “Akılcı ilaç kullanımının alfabesi” T.C. Să̆glk Bakanlı̆̆ı Săğlk Projesi Genel Koordinatörlüğ̈̈, 10s, Ankara, 1993

[25] Akıcı A., "İlaç güvenliliği izlemi hakkında genel bilgiler” $\boldsymbol{I} K \boldsymbol{U}$, 14, 8-10, 2006

[26] Mackenbach JP., Roskam AJ., Menvielle G., "Socioeconomic inequalities in health in 22 european countries" The New England Journal of Medicine, 358(23), 2468-2481, 2008

[27] Weitoft GR., Prof MR., Ericsson Ö., Ljung R., "Education and drug use in Sweden-a nationwide register-based study” Pharmacoepidemiology and Drug Safety, 17, 1020-1028, 2008 